\title{
Long-Term Cereal-Based Rotation TRIALS IN THE MEDITERRANEAN REgION: IMPLICATIONS FOR CROPPING SUSTAINABILITY
}

John Ryan,* Murari Singh, * and Mustafa Pala*

\section{Contents}

1. Introduction

2. Perspective on Global Long-Term Cropping System Trials

2.1. The concept of sustainable cropping $\quad 276$

$\begin{array}{ll}\text { 2.2. Relevance to current conditions } & 277\end{array}$

3. The Mediterranean Region $\quad 279$

3.1. Climate and environmental conditions $\quad 279$

3.2. Soil and water resources $\quad 282$

3.3. Cropping systems and rotations $\quad 284$

4. Overview of Long-Term Trials in the Mediterranean Region 285

4.1. North Africa $\quad 286$

4.2. West Asia $\quad 288$

5. Cropping System Trials at ICARDA in Syria 290

5.1. Rationale for long-term experimentation 290

5.2. Multiyear rotation and tillage trials 291

6. Synthesis of Long-Term Cropping System Trials at ICARDA 294

6.1. Crop yield trends: Cereal, food, and forage legumes 294

6.2. Quality components of grain and straw 298

6.3. Soil mineral nitrogen and nitrogen cycling 298

6.4. Potential benefits for soil quality 300

$\begin{array}{ll}\text { 6.5. Crop water use and water use efficiency } & 303\end{array}$

6.6. Phosphorus dynamics in arable soils and rangeland 305

$\begin{array}{ll}\text { 6.7. Economic assessment } & 306\end{array}$

7. Statistical Trends in Crop Rotations $\quad 307$

$\begin{array}{ll}\text { 7.1. Estimation of time trends } & 308\end{array}$

* International Center for Agricultural Research in the Dry Areas (ICARDA), PO Box 5466, Aleppo, Syria 
With increasing global populations particularly in developing countries, and a limited or even shrinking supply of arable land, the challenge to agriculture is to meet the world's food and fiber needs without reducing the capacity of the resource base (soil and water) to enable guaranteed production for posterity and also to accommodate society's environmental and energy concerns. The issue of production sustainability is all the more acute in semi-arid and arid regions of the world where drought and related biophysical factors create a fragile and uncertain environment for production. In the West, mainly in temperate regions, long-term agronomic trials have been invaluable in identifying new technologies and crop management systems that have contributed to enhanced crop output that is sustainable from the biological, environmental, and economical standpoints. Many of these trials continue to guide cropping trends into the foreseeable future. The Mediterranean region has served climatic constraints to its agriculture and despite being cultivated for millennia, it is largely food deficient. Yet long-term cropping experiments that could direct agricultural production in a sustainable manner are relatively rare, and even most of such trials are of recent vintage. This review offers a background perspective on factors related to crop, production, and subsequently examines the various multiyear cropping system/ tillage trials in countries of North Africa and West Asia that border the Mediterranean. Special emphasis is given to the wide range of trials conducted in Syria by the International Center for Agriculture Research in the Dry Areas across a range of rainfall zones that are typical of the region as a whole. The goal of many trials was to identify cropping systems as a substitute for fallow and continuous cereal cropping with implications for improved water-use efficiency (WUE), crop quality, soil quality, and fertilizer use. Lessons learned from the trials are highlighted as well as future directions for cropping systems research.

\section{INTRODUCTION}

Since the dawn of man's existence, the quest to acquire enough food and clothing has been a constant challenge in order to guarantee survival of the human species. The turning point for mankind took place about 10-12 thousand years ago when hunting/gathering slowly gave way to nomadic animal herding and settled agriculture with cultivated crops. Thus began the concept of land use (Harlan, 1992). With permanent settlements, which developed in various parts of the world, notably in the Mediterranean region, that is, the "Fertile Crescent of the Near East," the beginning of human civilization was set in motion. A more stable food supply from cultivated crops in well-watered river valley ensured better nutrition and consequently high survival rates and rapid population growth. World 
populations grew exponentially to such an extent that concerns were raised that mankind would outgrow the very resources that sustained them. Despite continued population growth in the 19th and 20th centuries, the gloomy predictions of Malthus were downplayed as advances in agricultural technology, combined with exploitation of new lands for cultivation, produced food and fiber in abundance, indeed surpluses, especially in developed countries (Borlaug, 2003).

However, in the modern era, actual and predicted growth rates in developing countries leave little grounds for complacency as far as balancing the food demand-supply equation is concerned. As we face a world of over 6 billion people, current global food stocks are at historically low levels, with dim prospects for Africa, and some countries of Asia and Latin America, getting out of the food-deficit hole. As society grapples with this monumental concern, with its implication for the environment and maintenance of global peace, the major question is "Can the world meets the food and fiber needs of its burgeoning populations without damaging its resource base?" In short, production sustainability that is compatible with soil and environmental presentation is a priority for mankind (Lal, 2001).

Of major agro-ecosystems of the world, particular concern in relation to food production system and its impact on the land-resource base is focused on semi-arid areas of the world where mostly rainfed cropping is practiced within the prevailing climatic constraints (Steiner et al., 1988). Much of the world's drylands are in developing countries and are characterized by low crop productivity, limited irrigation potential, weak administrative and agricultural research infrastructures, and unrelenting pressure on natural resources due to escalating growth in human and animal populations (Ryan, 2002a,b). Despite the attention that has been given to irrigated and the successes of the Green Revolution, dry areas of the world supply over $60 \%$ of the world's food (Stewart et al., 2006). As water scarcity has now been fully realized, along with urban industrial and recreational demands for water, the expansion in irrigational well inevitably stall (Rosegrant et al., 2002) and with it comes renewed crop production demands on semi-arid lands.

Despite the challenges inherent in dryland agriculture and the concerns about system sustainability (Stewart and Robinson, 1997), there are grounds for optimism that, with available soil and crop management technologies and improvements in water conservation, crop production in dry areas can be improved and sustainably managed (Lal, 1987; Peterson et al., 2006; Ryan, 2002a,b; Steiner et al., 1988). Indeed, given the global extent of dry areas, dryland agriculture may potentially contribute to carbon sequestration and thus mitigate the effects of climate change (Lal, 2002). As agriculture, whether involving crops or animals, influences its environment (FAO, 2002), future agricultural practices will have to be concerned about the ways in which it can do so either positively or negatively. 
Nowhere are the concerns about the practice of agriculture in rainfalllimited areas more acute than in the lands bordering the Mediterranean, especially to the south and east. Though the region is where settled agriculture began, especially in the cradle of civilization in the Fertile Crescent (Dregne, 2006) and the center of origin of many of the worlds food crops, notably cereals and pulses (Harlan, 1992), and the place where many of our farm animals (cattle, sheep, and goats) were domesticated, the region is largely a food-deficit one. Despite its antiquity, agriculture in the region is rapidly changing with more intensive land use, driven by population pressure (Ryan, 2002a,b). Given the drought-stressed environment of the region (Cooper et al., 1987; Smith and Harris, 1981) and its fragile soils (Matar et al., 1992), the implications of these changes on soil, water, and cropping systems call for a broad assessment as to their sustainability as the only way to reliably monitor long-term cropping practices, particularly with the introduction of new technologies and crop varieties, is through the medium of long-term cropping system trials.

Thus, in this review, we examine the various long-term trials with emphasis on crop rotations, a practice that dates back to Roman times in the Middle East (Karlen et al., 1994). Emphasis is given to food and forage legumes as alternatives to fallow, which is disappearing, and continuous cereal cropping, which is deemed sustainable. Consideration is also given to crop quality, nutrient cycling, soil quality, and water-use efficiency (WUE). As the fundamental issue is long-term viability of agricultural practices, a brief discussion follows on sustainability and lessons that have emerged from long-term cropping system trials elsewhere.

\section{Perspective on Global Long-Term Cropping SYSTEM TRIALS}

Agriculture by definition is a long-term process, and one that has evolved and changed with time, and is likely to continue to do so in ways we cannot predict for the future. Sustainability of agricultural practices is a relatively recent concern from the historical perspective. It only became an issue when people were obliged to farm the same land indefinitely and maintain its productivity. The fundamental rationale for long-term agricultural experiments is to assess where particular practices are likely to endure in any agro-ecosystem. Prior to teasing out the essence of various global longterm trials, it is pertinent to consider sustainability and how it is measured.

\subsection{The concept of sustainable cropping}

Sustainability is a concept of recent origin and one that is applicable at different levels and timescales, and indeed to different people. As anxieties developed about man's impact on the biosphere, sustainability enshrined the 
goal of conservation of habitats and biodiversity rather than exploitation, degradation, and pollution (Jones, 1993). Those concerns extend to the maintenance of food security, the necessary inputs to agriculture, and human equity. Agricultural sustainability must accommodate the array of interactions, whether positive or negative, between agricultural activities and the environment and society as a whole. Jones (1993) expanded on the different perspectives of sustainability depending on the stage of economic development. In developed countries, sustainability involves crop diversification and less dependence on nutrients and pesticides, while in developing countries the food production is the priority with lesser concerns for preserving the natural resource base. In both circumstances, the notion of sustainability extended to both internal and external resources. In short, the capacity of agriculture to maintain or even increase production over time without any damage to that potential or the environment is of concern for all mankind.

As the sustainability impinges on all sectors of society, the inevitable question raised is how to objectively measure the complex changes involved with sustainability. Detailed data of statistical validity are vital is such an endeavor (Barnett et al., 1994). Long-term agro-ecosystem experiments have been seen as the logical approach to evaluating long-term change in cropping systems. They provide an invaluable resource for assessing biological, biogeochemical, and environmental dimensions of agricultural sustainability, as well as serving as a basic for predicting the impact of climate change (Rasmussen et al., 1998). Notwithstanding the complexities of long-term trial evaluation, the most convincing evidence of the sustainability of any agricultural system comes from a long-term experiment with positive results (Steiner, 1995). Though the timeframe for agricultural sustainability assessment needs millennia (Sander and Eash, 1991), most global long-term experiments, with a few notable exceptions, fall within the human lifespan. These agroecosystem experiments constitute the largest temporal and spatial database presently available for determining the impacts of ecosystem change. Some brief comments on these trials as a background to considering agronomic systems trial in the Mediterranean region are given below.

\subsection{Relevance to current conditions}

Most long-term agronomic trials have been established in stable developed countries, with few in tropical climates or developing countries (Rasmussen et al., 1998), and none approaching the duration of conventional "longterm" trials. The standards by which such trials are measured are those established in Rothamsted (Jenkinson, 1991; Johnston, 1997, Johnston and Powlson, 1994). It is of interest to note that these trials were not initiated as long-term trials that they survive today and are of interest to many scientific disciplines even though the problems these trials set out to solve, mainly 
crop nutrient requirements, have long been solved. Because the trials were well designed and carefully managed, the Rothamsted trials survived despite the considerable financial and labor costs involved, while many others failed.

Of relevance to our consideration of Middle Eastern trials is the fact that cereal monoculture was sustainable in the trials provided organic or inorganic nutrients were used, but they also provided information on issues not even thought of at the beginning, that is, nitrogen $(\mathrm{N})$ and sulfur $(\mathrm{S})$ cycling and atmospheric contributions of nutrients, cadmium in $\mathrm{P}$ fertilizers, and soil organic matter (SOM) dynamics, all issues related to current environmental concerns. The message that long-term trials may yield new information not previously considered as time progresses is an important consideration related to any well-planned and well-designed long-term trial.

As we reflected on the Middle Eastern trials, it is worth recalling the broad objectives of long-term experimentation as outlined by Johnston and Powlson (1994). These are: (1) test the sustainability of a particular cropping system over a long time span and determine what changes are needed to enhance productivity and maintain sustainability, (2) generate data of value to farmers to improve cropping systems, (3) provide a means for further scientific research on soil and plant processes which control soil fertility and crop production, (4) allow a realistic assessment of nonagricultural anthropogenic activities on soil fertility and crop quality, and (5) produce datasets for development of mathematical models to predict the likely effects of management practices and climate change on soils and their productive capacity.

An overview of the historic long-term trials in the United States, for example, "Morrow Plots" in Illinois (1876), "Sanborn Field" in Missouri (1888), "Magrudar Plots" in Oklahoma (1892), and Alabama's “Old Rotation” (1896) have messages of relevance to our study (Mitchell et al., 1991). Most important among these conclusions is that crop rotations and attention to established fertility practices, which may or may not include legumes and manuring, are essential to maintaining high and sustained production. While the most obvious concerns of applied research and farmers is maintenance of crop yields and providing cropping options and yield responses to fertilizers, particularly N, most of the world's long-term trials provide invaluable information on soil quality (Reeves, 1997). The long-term information on SOM has direct implications for maintenance of soil structure and is fundamental to conservation of agriculture and the shift in cultivation practices from conventional tillage to minimum tillage and no-tillage. These trials also provided a means of assessing the effect of soil management on carbon sequestration, an issue of increasing importance in the growing public debate on climate change and how it is impacted by agriculture. 


\section{The Mediterranean Region}

Areas of the world with a typical Mediterranean climate occur principally in the lands surrounding the Mediterranean Sea and in limited areas of other continents, for example, California in the North America, Chile in South America, Southwestern Australia, and at the southern fringes of South Africa. Because of its comparatively lesser developed economic state than the northern shores of the Mediterranean, we focus our attention in this review on the southern and eastern Mediterranean, that is, West Asia and North Africa (WANA) (Fig. 1). Therefore, it is pertinent to outline climatic and soil conditions that influence cropping in the WANA region.

\subsection{Climate and environmental conditions}

The Mediterranean region has a unique climate, mainly a cool moist season followed by a hot rainless one, and has been described by various authors (Cooper et al., 1987; Kassam, 1981). Typically, the cropping season commences in the fall (October-November) with the onset of the first rains and a decrease in temperature and evapotranspiration (ET). Rainfall generally peaks in the January-February period which coincides with minimum temperatures. Rainfall falls off in April-May which coincides with maximum crop growth prior to May-June harvest. Typical weather features, that is, temperature, rainfall, and ET, are illustrated in Fig. 2. Terminal drought invariably occurs at the end of the season in April-May. The key to coolseason winter cropping in Mediterranean environments is an excess of soil moisture from rainfall over evaporation demand at a time when temperature conditions permit crop growth. Later as evaporative demand exceeds rainfall, growth depends on residual soil moisture.

Rainfed or dryland crop production, which dominates agriculture in the Mediterranean region, takes place against a background of limited rainfall that is variable in both time and space. Rainfall is generally highest near the sea and in high-elevation areas. The rainfall gradient decreases inland and eventually rainfed cropping gives way to vast expanses of rangeland or steppe and deserts in some cases (Kassam, 1981). The discrepancies were clearly illustrated by Harris (1995) for lowland and highland areas in North Africa and West Asia in terms of rainfall, and temperature patterns, and consequently growing conditions. In some highland areas, for example, Anatolia in Turkey and Zagros Mountains in Iran, snow is common in winter, while crop-damaging frosts can also occur at high elevations and inland where the climate is more continental.

Dryland or rainfed cropping is generally practiced in the range of 200-600 mm year ${ }^{-1}$. Rainfall range and such farming occupies about 
Comp. by: SNijam Date:8/3/08 Time:17:10:12 Stage:2nd Revises File Path:/l pchns1301/WOMAT/Production/PRODENV/0000000001/0000007216/

0000000016/0000763768.3D Proof by: QC by: ProjectAcronym:bs: 
Comp. by: SNijam Date:8/3/08 Time:17:10:12 Stage:2nd Revises File Path://

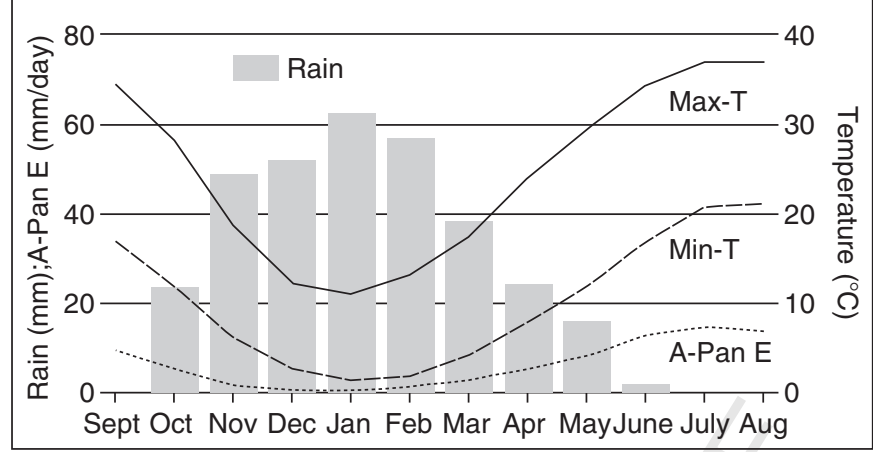

Figure 2 Long-term average for seasonal rainfall, A-Pan evaporation and maximum and minimum temperatures at Tel Hadya, Aleppo, Syria, approximating weather conditions in the Mediterranean region.

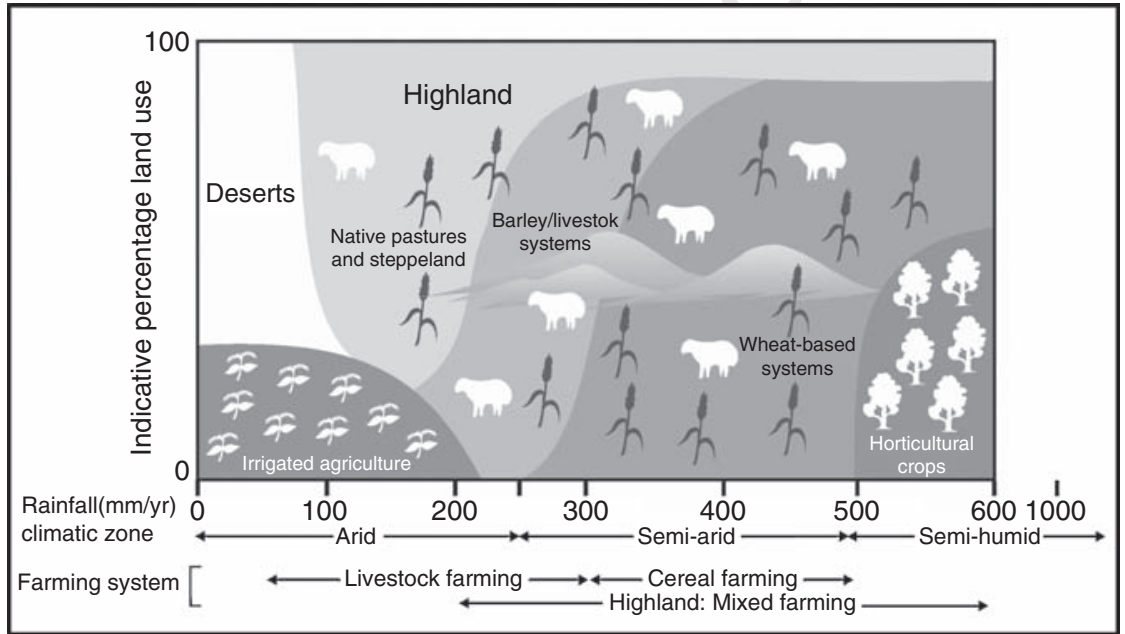

Figure 3 Schematic representation of agricultural production systems of the West Asia-North Africa (WANA) region.

125 mha in the WANA region (Kassam, 1981). There is a rainfall association between seasonal rainfall and cropping systems as illustrated in Fig. 3. Where rainfall is less than $200 \mathrm{~mm}$, cropping is unreliable without irrigation. Without irrigation, such low-rainfall areas are occupied by rangeland or true deserts. As rainfall increases, barley, which is relatively drought tolerant, commonly grows in the $200-300 \mathrm{~mm}$ zone and is associated with livestock production, mainly sheep. This then gives way, as rainfall increases, to wheat-based system (300-500 $\mathrm{mm}$ ) and above $500 \mathrm{~mm}$ where a range of field and horticultural crops/trees are grown. While rainfall is 
variable in any given year, the variability increases as the mean annual rainfall decreases, particularly with irregular distribution. Rainfall variability and its distribution pattern have implications for soil moisture dynamics and crop yields and underlines the need to analyze long-term weather data in terms of probability for accessing the implications of improved production practices. As the length of the growing season and rainfall totals are related (Kassam, 1981), based on degree-day requirement of crops and soil moisture availability, Smith and Harris (1981) indicated that the growing season would range from 90 to 180 days in the Mediterranean environment (Fig. 4).

The well-established relationship between crop yields and rainfall in dryland agriculture has been borne out in numerous field studies at The International Center for Agricultural Research in the Dry Areas (ICARDA) and elsewhere in the Mediterranean zone. As seasonal rainfall increased at three experiment stations on a rainfall transect, cereal yields increased (Keatinge et al., 1985). Similarly, seasonal rainfall had the greatest influence on yields in on-farm trials both for barley (Jones and Wahbi, 1992) and wheat (Pala et al., 1996). The above studies suggest that in crop rotation trials conducted over several years, rainfall would be a dominant influence on growth, which would be likely modified by the particular cereal rotation and its influence on residual soil moisture.

\subsection{Soil and water resources}

Agriculture in the Mediterranean region is inextricably linked to soil quality and water supply, whether from rainfall or irrigation. The soils of the region show considerable variation, reflecting the cumulative influence of climate,

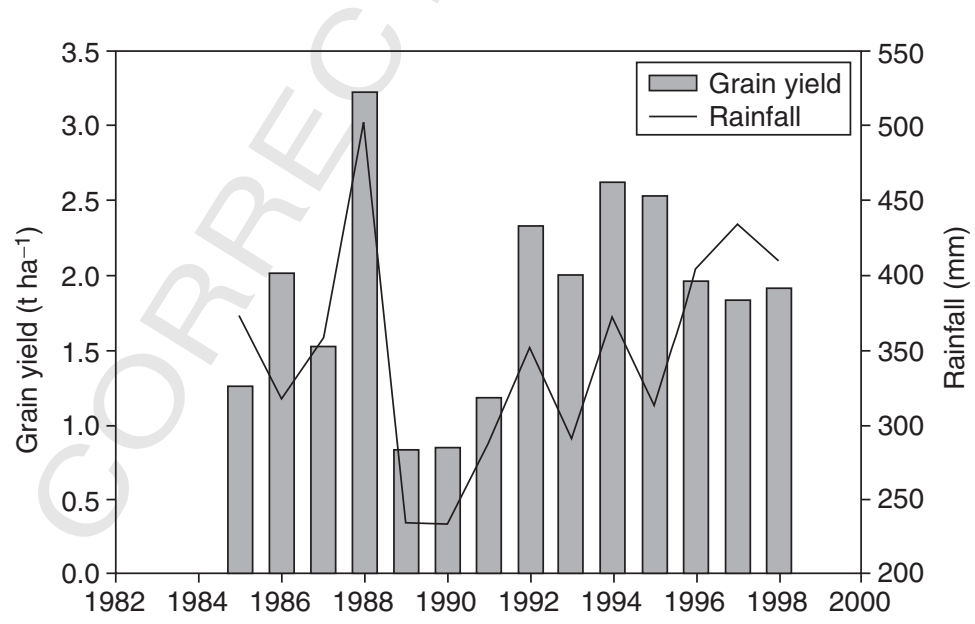

Figure 4 Relationship between average yearly rainfall and overall wheat grain yield from the Cropping Systems Productivity trial at Tel Hadya, Aleppo, Syria. 
topography, and the influence of man. The major soil orders are Inceptisols, Lithosols or shallow soils, Entisols, and Aridisols, with Vertisols being common in some areas (Kassam, 1981). Calcareous soils are dominant in the region, being derived from limestone residuum and are highly variable in terms of texture, depth, slope, and stoniness (Matar et al. 1992). While all soil properties impinge in one way or another on crop management and WUE, heavy clay soils pose a limitation on tillage operations while shallow soils have limited water-holding capacity and sloping soils promote erosion.

The dominant characteristics of the soils are the presence of free calcium carbonate $\left(\mathrm{CaCO}_{3}\right)$ and the low level of SOM, as both have a controlling influence on soil nutrients and their availability to plants. Levels of SOM are invariably low, being generally about $1-2 \%$ of the soil volume, with many soils in low rainfall areas being considerably less than $1 \%$ (Ryan, 1998). As a source of soil N, SOM can serve as a slow release nutrient source. However, the low equilibrium levels of SOM in semi-arid climates are conditioned by the temperature-moisture regime. Cultivation, especially with conventional tillage, exacerbates the decline of SOM in Mediterranean agriculture through $\mathrm{CO}_{2}$ emission to atmosphere (Ryan and Pala, 2007). Consequently, given the large demand of crops for $\mathrm{N}$, deficiencies of $\mathrm{N}$ are a constant feature of Mediterranean agriculture (Harmsen, 1984) and $\mathrm{N}$ fertilization is invariably required on an annual basis for nonlegume crops, especially cereals (Ryan, 2004).

While $\mathrm{CaCO}_{3}$ is normally a sizeable fraction of the soils in the region, its influence on soil chemical equilibria and solubility is significant, especially for P (Matar et al., 1992) and micronutrients such as iron and zinc (Rashid and Ryan, 2008). Prior to the advent of extensive chemical fertilization, P deficiency was widespread and endemic (Matar et al., 1992). However, with routine fertilizer use, available soil $P$ levels have built up in the soil and, as a result, severe deficiencies are rare (Ryan, 2004). While $\mathrm{Zn}$ deficiency is less directly related to $\mathrm{CaCO}_{3}$ than $\mathrm{P}$, deficiency of $\mathrm{Zn}$ is important in some areas, for example, Turkey (Cakmak, 1998) and Syria (Materon and Ryan 1995). Although boron (B) deficiency is influenced by both SOM and $\mathrm{CaCO}_{3}$, the incidence of deficiency can range from minimal in some countries (Khan et al., 1979) to severe in others (Rashid et al., 1994). While excessive levels of B can exist in Mediterranean soils, leading to toxicity to crops (Yau et al., 1995), the problem is related to geology rather than specific soil properties.

While the above brief comments reflect the possible influence of soil properties as they relate to crop production, these influences must be seen in the context of available water to sustain crop growth, whether it comes from the environment as rain or is provided from irrigation based on groundwater or surface sources. Despite the fact that supplemental irrigation has increased in the past decade (Oweis et al., 1998), both sources are limited and are unlikely to increase substantially; groundwater levels are dropping at 
a level of almost $1 \mathrm{~m}$ year $^{-1}$, with insignificant re-charge, while urban areas are competing with agriculture for surface water source. Only urban waste water is likely to increase as a source for irrigation with the additional benefits of nutrients for crops (Ryan et al., 2006). With this dismal scenario for expansion of irrigated agriculture, there is little option but to work within the confines of existing rainfall conditions and endeavor to exploit dryland cropping systems to achieve overall increases in output and maximize WUE.

\subsection{Cropping systems and rotations}

Notwithstanding the changes that have taken place in Mediterranean agriculture, descriptions of its cropping systems by Gibbon (1981) and Cooper et al. (1987) are still relevant as has been the case for millennia, the principal rainfed crops are cereals, mainly wheat and barley with small areas of rye, oats, and triticale of a local importance. While bread wheat and durum wheat dominate the more favorable rainfall zones $(+350 \mathrm{~mm})$, barley tends to be grown mainly in the lower rainfall zone. Bread wheat dominates in Turkey, while durum wheat mainly grows in Arab countries for flat bread, or burghul, and couscous. Barley is grown as a livestock feed (grain and straw) and is used also as human food in Morocco and Tunisia. As demand for livestock has increased, so too has the area devoted to barley, exceeding that of wheat in Syria and Morocco.

Food legumes mainly chickpea and lentils in rainfed areas, and faba bean in wetter areas or irrigated areas, are important crops of relevance to human nutrition in the Mediterranean region, and occupy about 5-10\% of the area devoted to cereals. Local demand for these crops is generally met, and some countries even export them. Other crops are diverse and are mainly grown in summer on stored moisture in favorable rainfall zones; these include watermelon, cantaloupe, sesame, cotton, sunflower, sorghum, and maize. Given the importance of livestock, efforts were made to include forage legumes as an alternative or supplement to grazed cereal stubble. Despite much effort to introduce and promote the use of a self-regenerating grazed forage, medicago or medic, the attempt has not met with success (Christiansen et al., 2000) but research on vetch is more promising (Jones and Singh, 2000a,b).

Though crop rotation, involving a cereal crop after an alternate crop or fallow, has its origins in Mediterranean agriculture (Karlen et al., 1994), the practice is of enduring relevance in dryland agriculture. Crop rotation serves as a break in disease buildup and promotes the conservation of stored moisture for the subsequent cereal crop; in the case of fallow, it leads to increased available $\mathrm{N}$ when a legume is used. In the past, the most common rotation was cereal/fallow, a moisture-conserving strategy to ensure an acceptable yield in the cereal year. Two types of fallow are practiced in 
the Middle East, that is, cultivated or clean fallow, which is common in West Asia, and "weedy" fallow which is common in North Africa (Cooper et al., 1987). In the latter case, the uncultivated fallow produces palatable weeds and volunteer cereals as a cheap livestock feed during the winter and spring months. With increasing land-use pressure, the incidence of fallow has progressively decreased to be replaced by continuous cereal cropping. In the higher rainfall areas, food legumes and summer crops are often grown in place of fallow, especially on deep soils in a 2-year rotation with cereals and, in some cases, a 3-year rotation with cereal, legumes, and summer crops.

While the benefits of rotations on cereal yields were recognized by farmers, we now know that these are attributed to a savings in soil moisture, though fallow efficiency is low and added fertility in the form of $\mathrm{N}$ for the fallowing cereal (Karlen et al., 1994). Additional benefits in terms of SOM are also important for soil aggregation and water relations, and enhanced biological activity (Rasmussen and Collins, 1991). While the beneficial effect of crop rotations can be masked by fertilizers, Karlen et al. (1994) concluded that "no amount of chemical fertilizer or pesticide can be fully compensated for crop rotation effects." The complexity of crop rotations in the Mediterranean region is accentuated by the grazing animal, especially in relation to animal droppings and the extent of grazed stubble.

\section{OVERVIEW OF LoNG-TERM TRIALS IN THE MEDITERRANEAN REgION}

Despite the antiquity of agriculture in the Middle East, being the center of origin of some of the world's food crops, for example, cereals, pulses, and nuts, and the major site of settled agriculture (Damania et al., 1998), allied to the concerns about land use intensification in this fragile ecosystem, few long-term cropping system trials exist in the region (Steiner and Herdt, 1993). In fact only one trial in Egypt dating back almost a century (1916) meet the criteria of Rasmussen et al. (1998) of at least 20 years to qualify to be considered as a long-term trial.

A number of administrative and socioeconomic factors could have contributed to the paucity of such cropping system trials. Primary among these is the general absence in most Middle Eastern countries of strong, well-advanced agricultural research and extension systems since such trials require considerable commitment of human and biophysical resources for many years. An additional factor is related to limited land availability for such extensive experiments at experimental station, which are usually relatively small (Ryan et al., 1990), or in farmers fields, where holdings are small (often $<10 \mathrm{ha}$ ) and where land tenure is dubious. 
Nevertheless, despite the limited duration of the comparatively few multiyear trials in the Mediterranean region, some have yielded useful indications of the longer term use of land in terms of sustainable crop yields and, in some cases, a perspective on soil properties that affect crop growth. In this brief overview, mention will be made to some of the main multiyear trials in North Africa and West Asia, exclusive of those conducted by ICARDA. Most of the trials had common features including fallow, continuous cropping, food and forage legumes, while others focused on tillage systems and residue management within a crop rotation context (Table 1).

\subsection{North Africa}

By comparisons with the West Asia region, there were relatively few multiyear dryland rotation trials in North Africa. Most of such trials were in Morocco, with only one of the current trials in Egypt being dryland; the others were irrigated reflecting the overwhelming importance of irrigated agriculture in Egypt. The only other dryland trial in North Africa was established in Algeria at Al Kroub (1992). Unfortunately, after the onset of civil unrest, the trial was discontinued. Consequently, the major findings related to rotation trials emanated from the semi-arid region of Morocco.

The ostensible objectives of the various agronomic system trials conducted in the central cereal-growing region of Morocco since 1982 were: (1) stabilize cereal production, (2) improve water and energy-use efficiency, (3) diversify cropping, and (4) reverse degradation. Most trials involved a tillage and residue management component and were conducted at the Sidi El-Aydi experiment station $(350 \mathrm{~mm})$ in the medium rainfall zone and Jemma Shaim $(287 \mathrm{~mm})$ in the lower rainfall zone. Most of the studies which formed the basic of doctoral theses (Bouzza, 1990; Kacemi, 1992; Mrabet, 1997) showed that clean-tilled fallow was essential to maintaining cereal yields under conditions in semi-arid Morocco (low and variable rainfall, deep clay soils), but the no-till system increased yields by comparison with conventional tillage as a result of higher WUE. Maintenance of cereal residues (stubble) on the soil surface helped to reduce evaporation and increase infiltration and contribute to WUE. Multiyear studies by Mrabet and coworkers (Bessam and Mrabet, 2003; Mrabet et al., 2001) showed that the no-till system increased both SOM and total soil N, mainly in organic form.

The issue of land use sustainability is nowhere more urgent than in Egypt, where land and water resources are limited and where population and land-use pressure is increasing; indeed urbanization is removing land from agriculture uses. Cropping intensity is around 180\% due to irrigation and favorable year-round growing conditions; the main irrigated crops are cotton, wheat, rice, maize, and berseem as an animal fodder. Overuse of $\mathrm{N}$ fertilizer and salinity due to inadequate drainage were seen as some of the 
Comp. by: SNijam Date:8/3/08 Time:17:10:15 Stage:2nd Revises File Path://

Table 1 General details of some long-term trials in the Mediterranean region, excluding ICARDA's trials

\begin{tabular}{|c|c|c|c|c|}
\hline Country & Location & $\begin{array}{l}\text { Year } \\
\text { established }\end{array}$ & Rotation & Purpose \\
\hline Cyprus & $\begin{array}{l}\text { Dromalaxia, } \\
\text { Laxia }\end{array}$ & $\begin{array}{l}1982 \\
1981\end{array}$ & $\begin{array}{l}\text { Barley/barley } \\
\text { Fallow/vetch }\end{array}$ & $\begin{array}{l}\text { Crop yields, } \\
\text { fertilizer } \\
\text { response }\end{array}$ \\
\hline Turkey & Haymana & 1982 & $\begin{array}{l}\text { Wheat/ } \\
\text { legumes }\end{array}$ & $\begin{array}{l}\text { Yield } \\
\text { sustainability, } \\
\text { water use } \\
\text { efficiency }\end{array}$ \\
\hline Algeria & Al Kroub & 1992 & $\begin{array}{l}\text { Wheat/ } \\
\text { legumes }\end{array}$ & $\begin{array}{l}\text { Yield trends, } \\
\text { grazing }\end{array}$ \\
\hline Morocco & Settat, Abda & $\begin{array}{l}1989 \\
1986\end{array}$ & $\begin{array}{l}\text { Medicago/ } \\
\text { cereals } \\
\text { Legumes/ } \\
\text { cereals }\end{array}$ & $\begin{array}{l}\text { Pasture } \\
\text { productivity } \\
\text { Tillage } \\
\text { methods }\end{array}$ \\
\hline Egypt & $\begin{array}{l}\text { Delta, } \\
\text { Coast, } \\
\text { Reclaimed } \\
\text { desert }\end{array}$ & 1996 & $\begin{array}{l}\text { Wheat, cotton, } \\
\text { rice, berseem, } \\
\text { beans }\end{array}$ & $\begin{array}{l}\text { Fertility } \\
\text { buildup and } \\
\text { maintenance, } \\
\text { water use, } \\
\text { salinity control }\end{array}$ \\
\hline Jordan & $\begin{array}{l}\text { Mushaggar, } \\
\text { Maro, } \\
\text { Ramtha }\end{array}$ & 1991 & $\begin{array}{l}\text { Lentil, } \\
\text { chickpea, } \\
\text { vetch/cereal }\end{array}$ & $\begin{array}{l}\text { Tillage } \\
\text { methods }\end{array}$ \\
\hline Lebanon & $\begin{array}{l}\text { Terbol, } \\
\text { Kfardane }\end{array}$ & 1990 & $\begin{array}{l}\text { Wheat/ } \\
\text { legume }\end{array}$ & $\begin{array}{l}\text { Assess yield } \\
\text { and biological } \\
\text { nitrogen fixation }\end{array}$ \\
\hline Iran & Marageh & 1996 & $\begin{array}{l}\text { Wheat/ } \\
\text { legume }\end{array}$ & $\begin{array}{l}\text { Sustainable } \\
\text { yields }\end{array}$ \\
\hline
\end{tabular}

sustainability issues in irrigated agriculture. Limited rainfed agriculture is practiced, for example, sandy coastal areas.

In view of the need to assess the impact of intensification on cropping systems, several long-term trials were established at Sids in the Nile Valley (old irrigated lands, intensive cropping, and nutrient use); El-Serw in the North Delta (saline soils, water table, and water quality issues); Nubaria in the western reclaimed calcareous desert (low fertility, crusting, and new rotations); Bustan, newly reclaimed sandy soil (low fertility and water-holding capacity); and two dryland sites at North Sinai, for example, 
El-Barth $(100 \mathrm{~mm})$ and Raffah $(200 \mathrm{~mm})$, mainly barley cultivation and fruit trees. The preliminary activities that led up to the establishment of these long-term trials in 1994 are described in details by Abo Elenein et al. (2000). These complex trials involved various rotations that included legumes such as berseem and faba bean and the other crops commonly grown in Egypt under different water quantity and quality and fertilizer and manure use. The many variables in the study included crop yields, WUE, total water use, salinity and fertility monitoring, and water quality. Because of the complexity of these long-term rotation-based trials, several years are required before definitive conclusions can be made.

\subsection{West Asia}

One of the longest rotation trials was established at Haymana, near Ankara in Turkey (1982) on-going the largest cereal producer in the Middle East and one of the few countries that is currently self-sufficient in food. As a result of cropping intensity, fallow, which was the common farmers practice, had been reduced by $40 \%$ compared to previous incidence of about $8 \mathrm{~m}$ ha. The quest was to identify suitable alternative crops adapted to the cereal-produced Anatolian plateau. The trial involved a range of crops (wheat, winter and spring lentil, chickpea, vetch, safflower, sunflower, cumin) and fallow in 2-, 3-, and 4-year rotations (Karaca et al., 1989).

Yield assessment indicated no reduction in cereal production after both winter and spring lentil and sunflower compared to fallow, while yields were considerably reduced by continuous wheat and to a lesser extent safflower, an effect related to soil moisture depletion (Karaca et al., 1989). In a later reporting of the trial results (Avcin and Avci, 1992), cereal yields after chickpea, lentil, vetch, and cumin were close to, or exceeding, yields after fallow, but the lowest again were safflower and continuous wheat. All crops, except safflower and wheat, contributed more to the available soil $\mathrm{N}$ pool than fallow. Vetch contributed the most mineral $\mathrm{N}$ in the soil profile. This trial having obtained crop yield data for 25 years is now focusing on the economic assessment of the trial as well as related soil physical properties. (Though a similar rotation trial was established in an environment similar to Haymana at Marageh in western Iran, it was terminated after a few years.)

Similar concerns about cropping system sustainability were expressed in Lebanon as in Turkey. If anything, cropping intensification and land-use pressure is even greater in Lebanon, especially in the Bekaa Valley, the country's main agricultural area. The multiyear trial conducted in the Valley for six seasons (1996-2001) sought to assess continuous barley cropping and identify suitable alternatives in rotation with barley (Yau et al., 2003). The crops were lentil, bitter vetch, common vetch for both grazing and hay, medics for grazing, and vetch mixed with barley for hay. The barley/vetch 
rotation yielded $44-80 \%$ more barley grain and $27-53 \%$ more barley straw than the barley monoculture over the 6-year period. The study clearly indicated that the prevailing practice of barley monoculture in the drier northern Bekaa region was not a viable practice and indicated the desirability of introducing vetch as an animal feed in the cropping system.

The research in vetch/barley in Lebanon paralleled earlier work in Cyprus where rotation trials were established in 1980 at Laxia $(250 \mathrm{~mm})$ and at Dromalaxia $(350 \mathrm{~mm})$ in 1981. Barley was considered for grain and hay and vetch for hay in relation to fallow and continuous cropping. Nitrogen $\left(0,30,60,90 \mathrm{~kg} \mathrm{~N} h^{-1}\right)$ was incorporated into the barley treatments. These studies showed that barley/vetch was consistently more productive than continuous barley or fallow (Papastylianou, 1993). While the studies showed a wide range of critical soil nitrate in relation to yield responses (30-100 $\mathrm{mg} \mathrm{NO}_{3} \mathrm{~kg}^{-1}$ ) in the $0-15 \mathrm{~cm}$ soil layer, the author concluded that tissue testing was a more reliable guide for $\mathrm{N}$ fertilization application rates (Papastylianou, 1997). Reinforcing the argument for substituting an economic crop instead of fallow, Orphanos and Metochis (1994) showed that contrary to established belief, the efficiency of fallow in these rotations was low; in only 4 of the 12 years did fallow add more than $45 \mathrm{~mm}$ of moisture to the following cereal, and in some years the moisture conserved from fallow was less than in cropped rotations.

Although Central Asia is not in the Mediterranean region and its climate is continental, it does have features of a Mediterranean climate and is under the current mandate of ICARDA (Ryan et al., 2004). Summer fallow fallowed by $2-3$ years of wheat or barley was traditionally practiced, but research efforts sought to find alternative crops to fallow, as in the Mediterranean area (Suleimenov et al., 2004). Though no long-term rotation trials as such were established in the newly independent republics, alternative rotations were assessed over a 3-year period; these involved varying tillage systems (deep, reduced, zero). The rotation with oats and dry pea were significantly higher yielding than fallow (followed by wheat, wheat, barley). The authors concluded that conservation tillage was as good as or more effective than conventional tillage and should be combined with the improved rotations without fallow. The absence of fallow was also shown to increase SOM, and therefore carbon sequestration, and to reduce erosion.

As Jordan has similar climatic characteristic as Syria, and to a lesser extent Lebanon, in terms of rainfall and temperature distribution and the limited area of arable land for rainfed cropping, a similar range of cereal-based rotations are practiced. Research and demonstration efforts sought to replace fallow with sown pastures (vetch) and food legumes (Taimeh et al., 1999). While no long-term rotation trials as such were established in Jordan, results of trials at the various experiment stations questioned the use 
of summer fallow. The effectiveness of the rotations in terms of WUE (wheat/vetch wheat/lentil/melon) was greatly influenced by the type of tillage adapted.

\section{Cropping System Trials at ICARDA in Syria}

In the initial years after its establishment, ICARDA focused on identifying crop growth constraints and assessing fertilizer and management facts in single-season field trials. Soon it became apparent that the longer term perspective was needed, especially given the annual variability in weather conditions that influenced crop yields.

\subsection{Rationale for long-term experimentation}

When ICARDA was founded in 1977, it was at a time when agriculture in the region of WANA was beginning to experience change, as was society at large in most countries. The drive to gradually shift from a traditional low input-low output agriculture that had been practiced from time immemorial to a more market-driven intensive agriculture was fueled by regional and global factors (Ryan, 2002a,b). Land use pressure was linked to rapid population growth in most Middle Eastern countries, with growth rates, especially in rural areas being among the highest in the world, additionally the region was impacted by global trends that were already expressed decades ago in developed countries, that is, increasing use of mechanization and use of chemical inputs, notably chemical fertilizers. These developments led to a substantial increase in agricultural output, notably wheat, making Syria self-sufficient for the first time in decades (Pala et al., 2004). While irrigation was encroaching the dominant cereal-dominated dryland sector (Oweis et al., 1998), concerns about the sustainability of irrigation have only intensified as the region's renewable water on a per capita basis is among the lowest in the world.

With more intensive use of a limited and fragile soil resource base in a food-deficit area of the world, concerns about sustainability inevitably arose. Threats to the production environment in the long term were perceived to occur across the agricultural spectrum from rainfed and irrigated agriculture to rangeland grazing (Jones, 1997). Soil fertility decline, soil erosion and degradation, and aquifer depletion were all stated concerns. The initial research program at ICARDA focused on identifying crop growth constraints and on short-term maximization of crop production. However, it was soon realized that a longer term perspective of the changes in production systems was needed; the effect of cropping intensification could only be realistically assessed by long-term trials. This thinking set the scene for the 
many long-term trials established in the early 1980s (Ryan and Abdel Monem, 1998).

It soon became clear that cumulative effect of crop management would take variable time periods to express itself depending on whether the parameter of concern was yields of grains and straw for the cereals, yields of food legumes, forage yields, animal offtake of grazed pastures, WUE, or the influence on soil physical, chemical, or biological properties. When the various trials were being established, issues such as SOM and its potential relationship with the environment and climate change was not yet articulated concerns of agricultural scientists, particularly agronomists. Similarly, conservation tillage and compost disposal had yet to emerge as the concerns they are today. Thus, the suite of multiyear trials, or long-term ones in the context of ICARDA, though often overlapping and with minimal coordination, sought to address issues perceived to be important objectives of long-term research as well as accommodating evolving concerns of relevance to crop production and the environment.

\subsection{Multiyear rotation and tillage trials}

The many long-term cropping system trials initiated by ICARDA were established in the 1980s, with most being terminated within 10-15 years. Most trials were conducted at the main station of Tel Hadya (latitude $36^{\circ} 01^{\prime}$, longitude $36^{\circ} 56^{\prime}$ ) $30 \mathrm{~km}$ south of Aleppo and representing the medium-rainfall zone $(300-400 \mathrm{~mm})$ with an average of $340 \mathrm{~mm}$, with considerable interannual and interseasonal variation. Forming a rainfall gradient, some trials were conducted in the drier barley-based low rainfall zone at Breda (latitude $35^{\circ} 56^{\prime}$, longitude $37^{\circ} 10^{\prime}$ ), with a long-term rainfall of $280 \mathrm{~mm}$ and others in the higher rainfall zone at Jindiress (latitude $36^{\circ} 26^{\prime}$, longitude $36^{\circ} 44^{\prime}$ ), with a long-term seasonal average rainfall of $446 \mathrm{~mm}$. However, Tel Hadya and Breda were the main experimental sites, with rainfall being the main difference. Relatively minor trial sites in terms of field trials included higher rainfall sites at Terbol and Kfardane in nearby Lebanon's Bekaa Valley and Kamishly in northwest Syria, and two drier sites at Gherife and Maragha. Details of locations' weather, cropping systems, and soil classification and properties are included in an ICARDA research station and site survey (Ryan et al., 1997).

A brief sketch of the various long-term trials conducted directly by staff at ICARDA is presented in Table 2 based on modification of an earlier list of Ryan and Abdel Monem (1998). Reference to the various categories of long-term crop rotation/tillage trials is pertinent. As Tel Hadya is in the wheat-growing zone, all the wheat-based trials were located there. These included the 2-course "Cropping Systems Productivity" trial, which was the most extensive in terms of area, and the longest duration, and the 3 -course rotation with emphasis on tillage. Other wheat-based trials at 
Table 2 Multiyear cropping system trials conducted by ICARDA at various locations in syria

\begin{tabular}{|c|c|c|c|}
\hline Brief title/location & Duration & Main crops & General purpose \\
\hline $\begin{array}{l}\text { 1. A 2-course } \\
\text { "Cropping } \\
\text { Systems } \\
\text { Productivity" } \\
\text { (TH) }\end{array}$ & 1983-1998 & $\begin{array}{l}\text { Wheat/ } \\
\text { chickpea, } \\
\text { lentil, medic, } \\
\text { vetch, fallow, } \\
\text { wheat }\end{array}$ & $\begin{array}{l}\text { System } \\
\text { productivity (crop } \\
\text { yields, animal } \\
\text { offtake), water use } \\
\text { efficiency, } \mathrm{N} \text { use } \\
\text { efficiency, physical } \\
\text { and chemical } \\
\text { properties }\end{array}$ \\
\hline $\begin{array}{l}\text { 2. A 2-course } \\
\text { barley-based } \\
\text { rotation }(\mathrm{TH})\end{array}$ & 1985-2004 & $\begin{array}{l}\text { Barley/medic, } \\
\text { vetch, fallow }\end{array}$ & $\begin{array}{l}\text { Assess grazing } \\
\text { systems, yields, } \\
\text { animal production, } \\
\text { soil quality }\end{array}$ \\
\hline $\begin{array}{l}\text { 3. A 3-course } \\
\text { wheat tillage } \\
\text { rotation (TH) }\end{array}$ & 1986-1998 & Wheat/lentil & $\begin{array}{l}\text { Crop yields, water } \\
\text { use efficiency, fuel } \\
\text { use efficiency }\end{array}$ \\
\hline $\begin{array}{l}\text { 4. Tillage systems/ } \\
\text { sowing dates } \\
\text { (TH) }\end{array}$ & 1985-1994 & Wheat/lentil & $\begin{array}{l}\text { Crop yields, water } \\
\text { balance }\end{array}$ \\
\hline $\begin{array}{l}\text { 5. Stubble } \\
\text { burning } \\
\text { (TH) }\end{array}$ & 1978-1994 & Wheat/lentil & $\begin{array}{l}\text { Stubble burning, } \\
\text { seedbed } \\
\text { preparation on } \\
\text { yields/soil } \\
\text { properties }\end{array}$ \\
\hline $\begin{array}{l}\text { 6. Continuous } \\
\text { barley } \\
(\mathrm{TH}, \mathrm{Br})\end{array}$ & 1986-1996 & Barley, fallow & Grain, straw yields \\
\hline $\begin{array}{l}\text { 7. Forage } \\
\text { legume/barley } \\
(\mathrm{TH}, \mathrm{Br})\end{array}$ & 1982-1990 & $\begin{array}{l}\text { Barley, vetch, } \\
\text { fallow }\end{array}$ & $\begin{array}{l}\text { Yields, protein } \\
\text { offtake, chemical } \\
\text { properties }\end{array}$ \\
\hline $\begin{array}{l}\text { 8. High } \\
\text { phosphate } \\
\text { grazing }(\mathrm{TH})\end{array}$ & 1984-1990 & Nature pasture & $\begin{array}{l}\text { Herbage seed } \\
\text { productivity, } \\
\text { animal output }\end{array}$ \\
\hline $\begin{array}{l}\text { 9. Straw } \\
\text { management } \\
(\mathrm{TH})\end{array}$ & 1996-2008 & $\begin{array}{l}\text { Barley/lentil, } \\
\text { vetch }\end{array}$ & $\begin{array}{l}\text { Compost, tillage } \\
\text { depth versus yields, } \\
\text { soil properties }\end{array}$ \\
\hline $\begin{array}{l}\text { 10. Legume } \\
\text { biological } \\
\text { nitrogen } \\
\text { fixation (TH, } \\
\text { Ter, Kfar) }\end{array}$ & 1991-1994 & $\begin{array}{l}\text { Vetch, } \\
\text { lathyrus, pea }\end{array}$ & $\begin{array}{l}\text { Symbiotic N } \\
\text { fixation residual } \\
\text { effects on wheat }\end{array}$ \\
\hline
\end{tabular}


Comp. by: SNijam Date:8/3/08 Time:17:10:16 Stage:2nd Revises File Path://

Table 2 (continued)

\begin{tabular}{|c|c|c|c|}
\hline Brief title/location & Duration & Main crops & General purpose \\
\hline $\begin{array}{l}\text { 11. Rangeland } \\
\text { shrubs (Mar) }\end{array}$ & 1989-1998 & $\begin{array}{l}\text { Edible shrubs/ } \\
\text { saltbush }\end{array}$ & $\begin{array}{l}\text { Plant biomass, } \\
\text { livestock, weight } \\
\text { gain, economics }\end{array}$ \\
\hline 12. A triplex/barley & 1990-1995 & $\begin{array}{l}\text { Barley, forage } \\
\text { legumes }\end{array}$ & $\begin{array}{l}\text { Crop yields, system } \\
\text { output }\end{array}$ \\
\hline $\begin{array}{l}\text { 13. Barley tillage/ } \\
\text { stubble mulch } \\
(\mathrm{Br})\end{array}$ & 1989-1994 & Barley, vetch & Crop yields, soil \\
\hline $\begin{array}{l}\text { 14. "New } \\
\text { Rotation" (Br) }\end{array}$ & 1982-1990 & $\begin{array}{l}\text { Barley, vetch, } \\
\text { fallow }\end{array}$ & $\begin{array}{l}\text { Sustainable crop } \\
\text { productivity }\end{array}$ \\
\hline $\begin{array}{l}\text { 15. Phosphate } \\
\text { dynamics (Jin, } \\
\text { TH, Br) }\end{array}$ & 1986-1994 & $\begin{array}{l}\text { Wheat, barley/ } \\
\text { lentil, vetch }\end{array}$ & $\begin{array}{l}\text { Assess cereal, } \\
\text { legume yields, } \\
\text { available soil }\end{array}$ \\
\hline $\begin{array}{l}\text { 16. Wheat/medic, } \\
\text { vetch grazing } \\
\text { (Kam) }\end{array}$ & $\begin{array}{l}1986- \\
\text { continue }\end{array}$ & $\begin{array}{l}\text { Wheat/medic, } \\
\text { vetch, fallow }\end{array}$ & $\begin{array}{l}\text { Grazing } \\
\text { effectiveness } \\
\text { animal/crop yields }\end{array}$ \\
\hline
\end{tabular}

Abbreviations for sites: $\mathrm{TH}=$ Tel Hadya $(340 \mathrm{~mm}) ; \mathrm{Br}=$ Breda $(280 \mathrm{~mm})$; Jin $=$ Jindiress $(446 \mathrm{~mm})$; Ter = Terbol $(494 \mathrm{~mm}) ; \mathrm{Kfar}=$ Kfardane $(452 \mathrm{~mm}) ; \mathrm{Kam}=$ Kamishly $(438 \mathrm{~mm}) ; \mathrm{Ghr}=$ Gherife $(245 \mathrm{~mm})$; Mar = Maragha $(196 \mathrm{~mm})$.

Tel Hadya focused on timing of tillage systems of shallow, deep, and stubble burning (Pala et al., 2000). While one major barley-based rotation trial that focused on medic and vetch grazing was sited at Tel Hadya, most barley trials were at the Breda site which is representative of the barley-growing zone. Some barley trials were at both sites to reflect the influence of seasonal rainfall differences. These trials sought assess vetch as a forage legume to replace fallow or continuous cropping. The only barley or wheat trial that is on-going is the straw management one at Tel Hadya where the focus is on disposal of straw compost in vetch/cereal rotations under deep and shallow tillage.

A variety of longer term trials constituted the remainder of the cropping system trials at ICARDA. Dominant among these was the "P Dynamics" trial which was conducted within a cereal/legume rotation at the three main sites on the rainfall gradient: Jindiress, Tel Hadya, and Breda. One study over 3 years at Tel Hadya and colder sites in Lebanon examined biological nitrogen $(\mathrm{N})$ fixation and its residual effects on cereal yields. A few trials were oriented toward rangeland shrubs as a fodder source for sheep in single stands or stands in association with barley as an intercrop. One study dealt with the longer term effect of $\mathrm{P}$ fertilization on biomass yields and animal output from native pastures. 


\section{Synthesis of Long-Term Cropping System TRIALS AT ICARDA}

As the results of the various studies related to the long-term cropping system trials have been published in different journals and published media, we have made an attempt here to provide a brief synthesis of these results under a few broad headings.

\subsection{Crop yield trends: Cereal, food, and forage legumes}

In most of the long-term trials, sufficient and consistent grain, straw, and forage yield data were obtained to make valid conclusions regarding the effects of the various rotations. In the Cropping Systems Productivity trial, the yield trends observed by Harris (1995) after 7 years of the trial were relatively similar to overall yields recorded after 14 years when the trial was terminated (Ryan et al., 2008a). Despite the fact that yields varied greatly with seasonal rainfall being about 3-5 times higher in the high rainfall year (504 $\mathrm{mm}$ in 1987-1988) than in the lowest rainfall year (214 $\mathrm{mm}$ in 19891990), the order with respect to rotations was similar (Table 3). Highest mean yields were with fallow, and lowest with continuous wheat, with the legume rotations between those. The order of grain yields from the full 14 years of cropping was: fallow, melon (equivalent to fallow as a crop was not grown for 10 of the 14 years due to insufficient residual moisture), vetch, lentil, medic, chickpea, and continuous wheat. Straw yields followed a similar pattern as the harvest index was relatively stable. However, it should be noted that wheat yield after fallow was only once every two years, which makes its systems productivity slightly higher than that of continuous wheat. Systems productivity of rotation with legumes was much higher than wheat/fallow and continuous wheat cropping systems.

The response to applied $\mathrm{N}$ was influenced by the amount of $\mathrm{N}$ contributed by the legumes in the rotation and by the soil moisture. Thus, the relative response to $\mathrm{N}$ was highest for continuous wheat and fallow, and least for medic and vetch, which added fixed $\mathrm{N}$ to the soil. The overall mean wheat grain yield response to applied $\mathrm{N}$ across all the rotations was 1.55, $1.87,2.08$, and $2.21 \mathrm{Mg} \mathrm{ha}^{-1}$ for the $0,30,60$, and $90 \mathrm{~kg} \mathrm{~N} \mathrm{ha}^{-1}$ application rates. The respective values for straw were $2.61,3.31,3.78$, and $4.12 \mathrm{Mg} \mathrm{ha}{ }^{-1}$ for the four $\mathrm{N}$ application rates. The various wheat stubble grazing regimes (stubble retention or no grazing and medium and heavy grazing) had little or no effect on either grain or straw yields.

This trial confirmed the value of fallow, but as fallow is being phased out due to land-use pressure since the land remains idle during the alternate year, possible cropping alternatives were identified. Given the value of 
Comp. by: SNijam Date:8/3/08 Time:17:10:18 Stage:2nd Revises File Path://

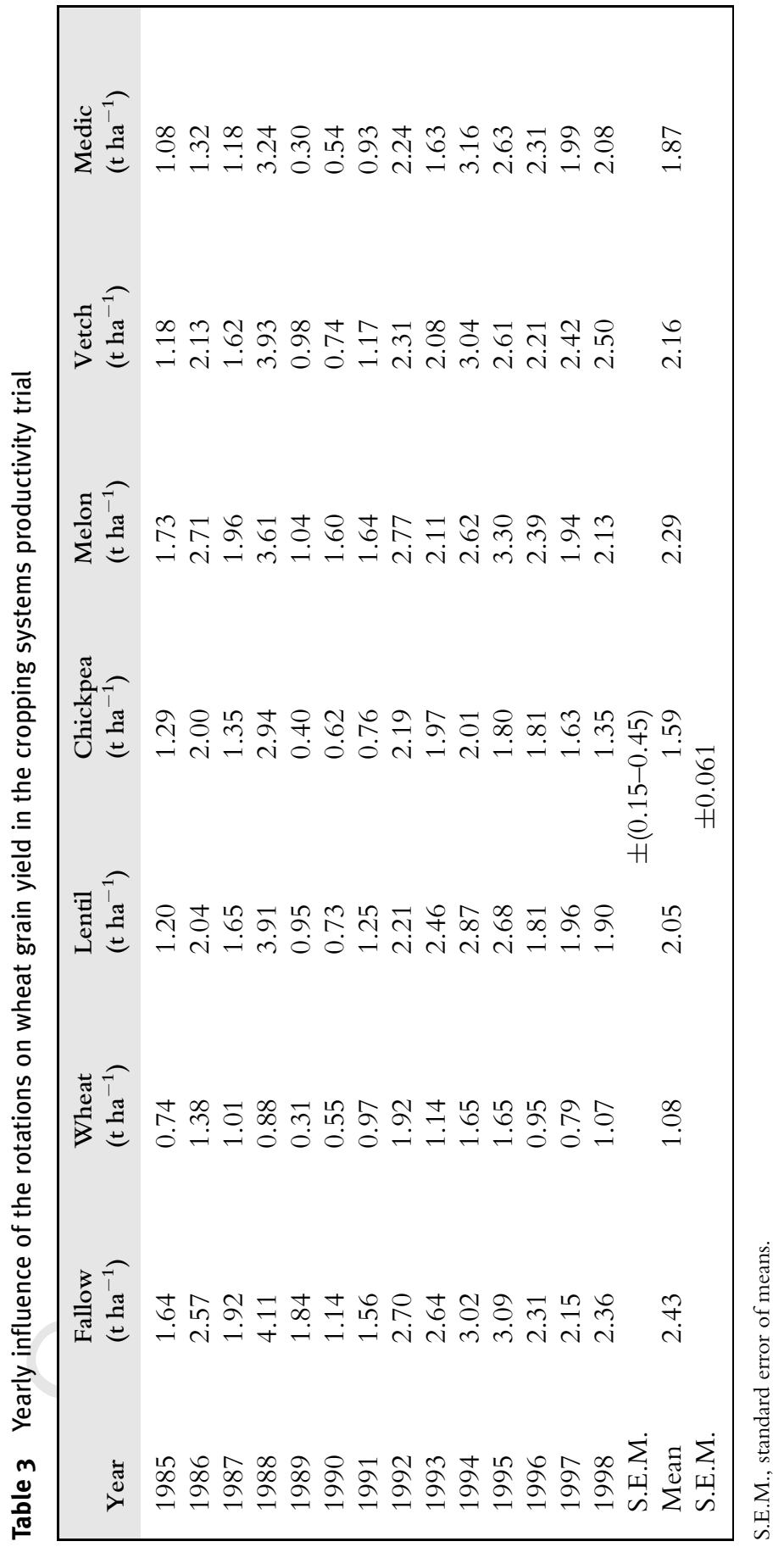


animal feed, vetch in particular was an attractive alternative rotation; however, for various agronomic and socioeconomic reasons, medic is unlikely to be adopted (Christiansen et al., 2000) despite its benefit in terms of soil $\mathrm{N}$ and SOM enhancement. Given favorable economics, the food legume-based rotations, chickpea and lentil, could contribute to sustainable cropping in the Mediterranean region. The consistently low yields from continuous cropping with wheat were due to moisture depletion and no added $\mathrm{N}$ in the "cereal" year, that is, the year when the alternative crops (legumes, fallow) were in the phase. While continuous cereal yields may have been increased by $\mathrm{N}$ fertilization in both years, the problem of disease buildup remains and thus the practice is less attractive than legumes, forage or food, in the cereal rotation.

Other rotation trials with wheat focused on tillage methods in the contest of a limited rotations (deep disking, chisel, ducksfoot) (Pala et el., 2000). Those trials evaluated types of tillage systems and timing of tillage operations. In the wheat/lentil/watermelon rotation, deep tillage had no advantage over a shallow sweep-type tillage system (conservation or minimum tillage) in terms of crop yields or WUE. The zero-till or no-till system suited lentil, but gave lower productivity in wheat due to large row spacing of drill $(30 \mathrm{~cm})$, the buildup of grassy weeds, and was not suitable for watermelon. As minimum tillage has higher energy-use efficiency, the authors concluded that it has more potential than conventional tillage even though it may not necessarily increase yields. However, zero-till systems with new drill available with narrower row spacing $(<20 \mathrm{~cm})$ seem to be compatible with minimum or conventional tillage systems according to recent research outputs (Pala et al., 2007).

Research on barley-related rotations was conducted mainly at the relatively dry Breda site with a few barley trials at Tel Hadya. In a 7-year trial at Breda, Jones $(2000 \mathrm{a}, \mathrm{b})$ showed that zero-tillage, or direct drilling, with cereal residue retention may marginally enhance soil moisture, but the yield effect on barley, either mono-cropped or in rotation with vetch, was small and nonsignificant. In the vetch/barley rotation, a small but consistent benefit to vetch was observed, that is, a $20 \%$ increase in vetch hay. However, given smallholders preference for barley dual reluctance to grow vetch as an alternate crop, Jones $(2000 \mathrm{a}, \mathrm{b})$ concluded that there is little to encourage the promotion of zero-tillage conservation in the farming systems of the very dry areas as represented by the Breda site in the $200-300 \mathrm{~mm}$ rainfall zone. However, recent studies showed just the opposite with appropriate drills when used particularly in drier years with improved water use efficiency (Pala et al., 2007).

In an expanded trial at both Breda and Tel Hadya, Jones and Singh (1995) compare six 2-course rotations with barley in combination with a fertilization regime $(\mathrm{N}, \mathrm{P})$. As anticipated, barley yielded most after fallow and more after legumes than with mono-cropped barley. On the basis of 
total dry matter production over the two crops in rotation, the barley/ legume rotation out-yielded barley/fallow or barley/barley. In terms of net $\mathrm{N}$ offtake, which is a measure of the feed value, the barley/legume rotation doubled that of the other rotations whether fertilized or not. Of the legumes, Lathyrus sativus was more productive than Vicia sativa. Rotations involving pure legumes were slightly more productive than legume/barley mixtures. While yields of the rotations were rainfall dependent, the variability was least in barley/fallow due to the carryover soil moisture.

In a series of comprehensive publications on barley rotations, Jones and Singh dealt with a comparison of rotations (Jones and Singh, 2000a), the role of feed legumes (Jones and Singh, 2000b), and barley mono-cropping (Jones and Singh, 2000c). In the 14-year study (Jones and Singh, 2000a), it was shown that the inclusion of legumes in barley-based rotations enhances the quantity and quality of feed production. A consistent effect of fertilization was shown, and without adequate fertilization there was a decline in yield relative to fertilized crop. Following a 6-year study at the two sites (Jones and Singh, 2000b), it was shown that narbon vetch may have greater potential in barley rotations in dry areas than common vetch or lathyrus, but its unsuitability for green grazing is a limitation.

In their assessment of barley mono-cropping, Jones and Singh (2000c) suggested that it is necessarily nonsustainable in the medium term, provided adequate annual fertilization is maintained, but risks of pest and disease build-up, in addition to the proven superiorly of legume/barley systems in terms of biomass yield and crude protein output, favor the introduction of some forage legumes in longer term barley sequences. While a strict rotation system may not be practical, or indeed acceptable to farmers in barley-sheep areas, the authors suggested that continuous barley might be interrupted every third or fourth year with a legume or fallow.

The most recent reporting of crop yields was from the 10-year composttillage trial at Tel Hadya (Pala et al., 2008). Barley yields were higher following application of compost every 2-4 years than following stubble burning or incorporating the stubble into the soil. Barley grain and straw yields were not significant, but were generally higher with the moldboard plow than with the conservation-type ducksfoot cultivator. The pattern for vetch was similar. Interestingly, the shorter barley/vetch rotation was not different in terms of yield than the longer 4-year rotation of wheat/vetch/barley/vetch.

The only other trial on barley at Tel Hadya was originally based on wheat (White et al., 1994). Following a number of years of the modified trial, especially with respect to grazing treatments, some preliminary observations were made on crop yields (Ryan et al., 2002). In the rotations of barley with barley, fallow, medic, and vetch, there was a consistent response to $\mathrm{N}$ fertilizer, being greater as seasonal rainfall increased. The difference between fertilized and control plots reflected the contribution of the legumes to soil $\mathrm{N}$ with higher $\mathrm{N}$-use efficiency. Barley yields were in 
order of fallow, vetch, medic, and continuous barley. However, rotational productivity was higher for the vetch and medic rotations compared to fallow or continuous barley.

\subsection{Quality components of grain and straw}

By comparison with yields in the long-term trials, quality components were less frequently considered. In the Cropping Systems Productivity trial, we measured proteins in grain and straw as this is important for human nutrition and animal nutrition in the case of sheep grazed on stubble (Ryan et al., 2008 b). Despite the anticipated variation between yields which was related to rainfall and how it influenced crop yields, there were clear differences due to rotations in terms of grain and straw $\mathrm{N}$ and thus protein. The highest $\mathrm{N}$ in the grain came from the medic rotation $(2.57 \%)$ followed by the vetch $(2.20 \%)$ while fallow was lowest $(1.80 \%)$ with values from the other rotations in between. The continuous wheat rotation, which yielded low, also had a low $\mathrm{N}$ concentration in the grain (1.95\%). The implications for nutrition are self-evident, with forage legume-based rotations yield grain of higher nutritional quality. However, other than meeting a minimum protein percentage, there is no premium for additional quality. The improvement in straw quality followed the same trend as grains, with about $60 \%$ more protein in the straw after medic than with fallow. Such differences in quality and protein intake are particularly significant where animals graze mainly on cereal stubble with little or no supplementation on access to protein-rich pasture. The only comparable study on irrigated wheat was a 2-year trial with several durum wheat (Mikhail et al., 2008) which showed that as yields increased with irrigation, protein concentration in grain and straw decreased, but this decline was counterbalanced by added fertilizer $\mathrm{N}$.

Studies with barley mainly focused on yields, but the same effect of legumes in the rotation was shown as with wheat. Various barley-based trials at the dry Breda site (Keatinge et al., 1988a,b) showed that chickpea, lentil, and vetch increased crop $\mathrm{N}$ concentration, and thus protein. Improved management such as $\mathrm{P}$ fertilizer reduced raw spacing and weed control enhanced biological $\mathrm{N}$ fixation leading to increased $\mathrm{N}$ uptake in the crop compared to traditional management. The residual effect of these legumes following barley crops was equivalent to $10 \mathrm{~kg} \mathrm{~N} \mathrm{ha}^{-1}$, a substantial improvement in nutrition.

\subsection{Soil mineral nitrogen and nitrogen cycling}

In the early years of most of ICARDA's long-term trials, there were limited measurements of forms of $\mathrm{N}$ of relevance to crop response. Following the initial sampling 6 years after the Cropping Systems Productivity trial began, Harris (1995) presented three years' data (1989-1991) for mineral and total N 
$(0-20 \mathrm{~cm})$ in all rotations and phases (Harris et al., 1995). These data showed a consistent effect of the legume rotations on $\mathrm{N}$, particularly the total amount mainly in the organic fraction with differences between the cereal and alternative phases. Subsequently, the complete dataset was compiled (Ryan et al., 2008c). Total N was significantly higher in the medic and vetch rotations, with lowest values with fallow and continuous cropping. The influence of rotations on total $\mathrm{N}$ roughly paralleled the labile and biomass $\mathrm{N}$ fractions (Ryan et al., 2008d). Enrichment in medic extended to $40-60 \mathrm{~cm}$ depth due to its rooting system. However, as mineral $\mathrm{N}$ (ammonium plus nitrate) is the pool which plants take up $\mathrm{N}$ and is enriched by mineralization, there was no consistent relationship with rotations. Interestingly, as the mean fertilizer $\mathrm{N}$ rate increased, so did the total $\mathrm{N}$, for example, $744 \mathrm{mg} \mathrm{N} \mathrm{kg}^{-1}$ in the control to $804 \mathrm{mg} \mathrm{kg}^{-1}$ at the highest $\mathrm{N}$ application rate. The variable stubble grazing had no consistent effect on either $\mathrm{N}$ form. Despite such a relationship between mineral $\mathrm{N}$ and total $\mathrm{N}$, a laboratory incubation study that eliminated the plant uptake factor, Ryan et al. (2003) showed that under favorable moisture and temperature conditions the mineralization potential from the medic rotation soil far exceeded that from the continuously cropped soil or the fallow.

The Cropping Systems Productivity trial served as a source of several $\mathrm{N}$-cycling studies based mainly on micro-plots within the rotations for a limited number of cropping seasons. McNeill et al. (1998) made estimates of the properties of $\mathrm{N}$ derived from the atmosphere by chickpea and lentil in the alternate phase of a cereal/legume 2-year rotation for three seasons (1993-1995) using isotopic dilution and residual ${ }^{15} \mathrm{~N}$ in the soil. Only a small proportion of the original fertilizer added (5\%) was utilized by plant uptakes plus any losses in the residual year indicating a slow remineralization rate of the immobilized labeled $\mathrm{N}$. In the same micro study, McNeill et al. (1996) estimated $\mathrm{N}$ uptake for chickpea ranging from 32 to $82 \mathrm{~kg} \mathrm{~N} \mathrm{ha}^{-1}$ and 18 to $82 \mathrm{~kg} \mathrm{~N} \mathrm{ha}^{-1}$ for lentil; these estimates were considered as function of the methodology used.

Several studies of Pilbeam and colleagues addressed various aspects of $N$ cycling in the Cropping Systems Productivity trial. By comparison with other more humid environments, Pilbeam (1996) indicated that the proportion of ${ }^{15} \mathrm{~N}$ recovered was higher in the soil and lower in the crop in dry environments such as Syria. In examining the influence of crop rotations on ${ }^{15} \mathrm{~N}$ recovery, Pilbeam et al. $(1997 \mathrm{a}, \mathrm{b})$ concluded that the benefits of growing wheat in rotation with fallow or a grain legume (lentil, chickpea) ranged from nothing to an equivalent application of $30 \mathrm{~kg} \mathrm{~N} \mathrm{ha}^{-1}$ to continuous wheat depending on the season and previous crop. Again, depending on the season, between 8 and $26 \%$ of the ${ }^{15} \mathrm{~N}$-labeled fertilizer was recovered in the shoot dry matter, while between 18 and $54 \%$ of the fertilizer remained in the soil, mostly in the $0-20 \mathrm{~cm}$ soil layer.

Two other papers dealt with $\mathrm{N}$ as related to fertilizer form and application rate (Pilbeam and Hutchison, 1998; Pilbeam et al., 1997a,b). 
While there was little difference between the three $\mathrm{N}$ sources (urea, ammonium nitrate, ammonium sulfate), the proportion of added $\mathrm{N}$ in the soil as inorganic $\mathrm{N}$ increased with the fertilizer application rate. Fertilizer application caused a significant increase in the amount of unlabeled soil $\mathrm{N}$ in the crop indicating a real added $\mathrm{N}$ interaction.

The large $\mathrm{N}$ losses indicated in those studies (Pilbeam and Hutchison, 1998; Pilbeam et al., 1997a,b) are a cause for concern in terms of fertilizer use efficiency and economic implications and is worthy of some elaboration. The losses are inconsistent with data of Abdel Monem (1986) at Breda and Tel Hadya that indicated maximum losses of $\mathrm{N}$ as $\mathrm{NH}_{3}$ from urea to be $11-18 \%$ at maximum. Similarly these losses were out of line with those of Garabet et al. (1998) at Tel Hadya under similar environmental conditions: The mechanisms postulated for the large $\mathrm{N}$ losses, that is, nitrate leaching, below the 1-m soil depth and denitrification, are not plausible for the reason that the wetting front rarely if ever reaches below that depth (Harris, 1995) and anaerobic conditions do not prevail to any extent in such dry environments. Rather the losses may be attributed to $\mathrm{NH}_{3}$ volatilization, a process that was accentuated since the $\mathrm{N}$ as urea was added in solution while the other studies (Abdel Monem, 1986; Garabet et al., 1998) use conventional solid fertilizer, or it may have been due to experimental error.

In summary, the various micro-plot studies on $\mathrm{N}$ cycling and the measurements of $\mathrm{N}$ forms in the soil have contributed greatly to what is known about $\mathrm{N}$ in the Mediterranean region (Harmsen, 1984). When related to crop responses to fertilizer $\mathrm{N}$, these studies have contributed to a body of knowledge of soil plant and fertilizer $N$ that is the basis for practices that improve fertilizer use efficiency in the interests of farm economy and the overall environment (Table 4).

\subsection{Potential benefits for soil quality}

Soil quality refers to physical, chemical, and biological properties of the soil, a concept that has been in vogue for several decades. However, when the long-term cropping systems/tillage trials were initiated at ICARDA in the early-mid 1980s, the primary focus was on sustainable crop yields and WUE. As SOM is a key indicator of quality as it influences biological activity, serves as a nutrient reservoir, and impacts soil aggregation, routine measurement of SOM was initiated in the fall of each year, several years after the Cropping Systems Productivity trial was established (Ryan, 1998). Most of other trials simply involved the measurement of SOM as a basic soil characteristic. The observation that SOM was significantly influenced by crop rotations, especially the forage legumes, medic and vetch (Table 5) gave rise to two studies related to soil physical properties.

The study of Masri and Ryan (2006) examined the influence of the seven rotations in the Cropping Systems Productively trial on soil aggregate 
Comp. by: SNijam Date:8/3/08 Time:17:10:20 Stage:2nd Revises File Path:// pchns1301/WOMAT/Production/PRODENV/0000000001/0000007216/

0000000016/0000763768.3D Proof by:

QC by:

ProjectAcronym:bs:

AGRON Volume:97007

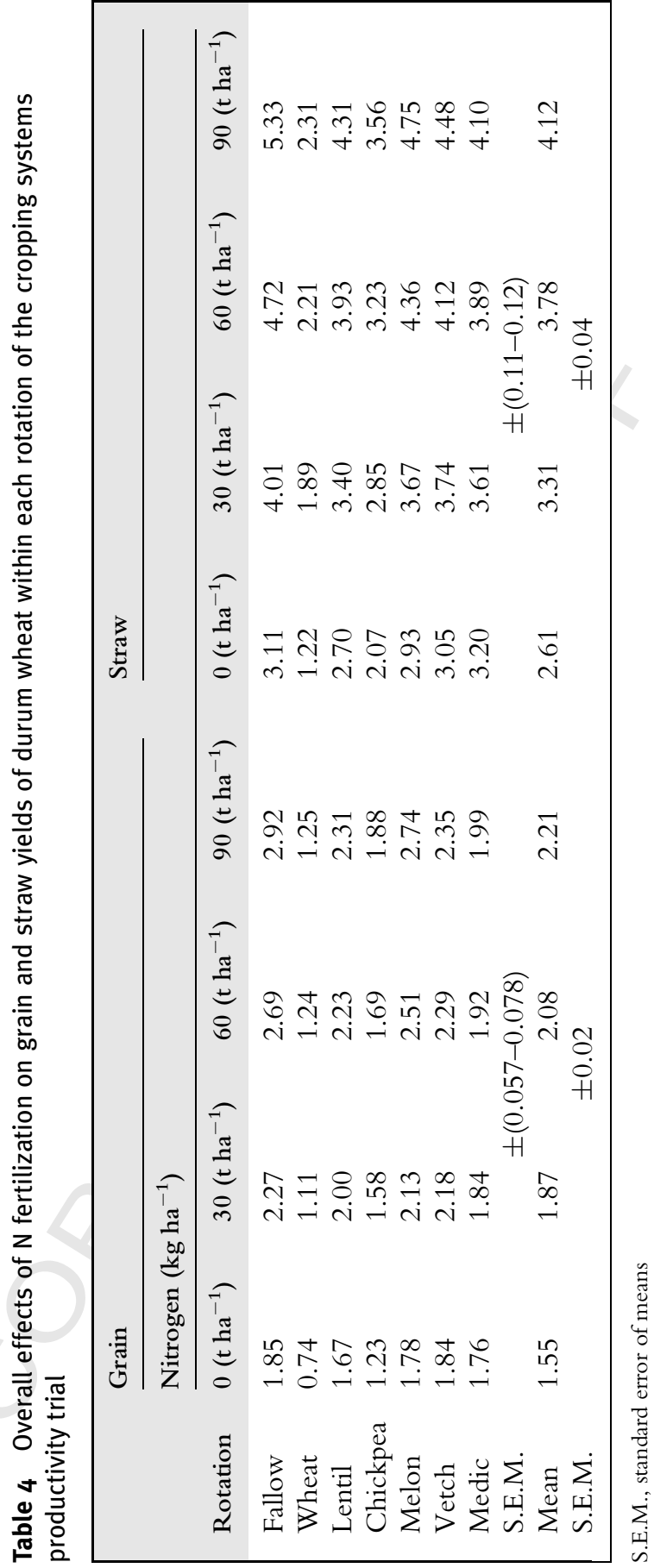


Comp. by: SNijam Date:8/3/08 Time:17:10:21 Stage:2nd Revises File Path:// pchns1301/WOMAT/Production/PRODENV/0000000001/0000007216/

0000000016/0000763768.3D Proof by:

QC by:

ProjectAcronym:bs:

AGRON Volume:97007

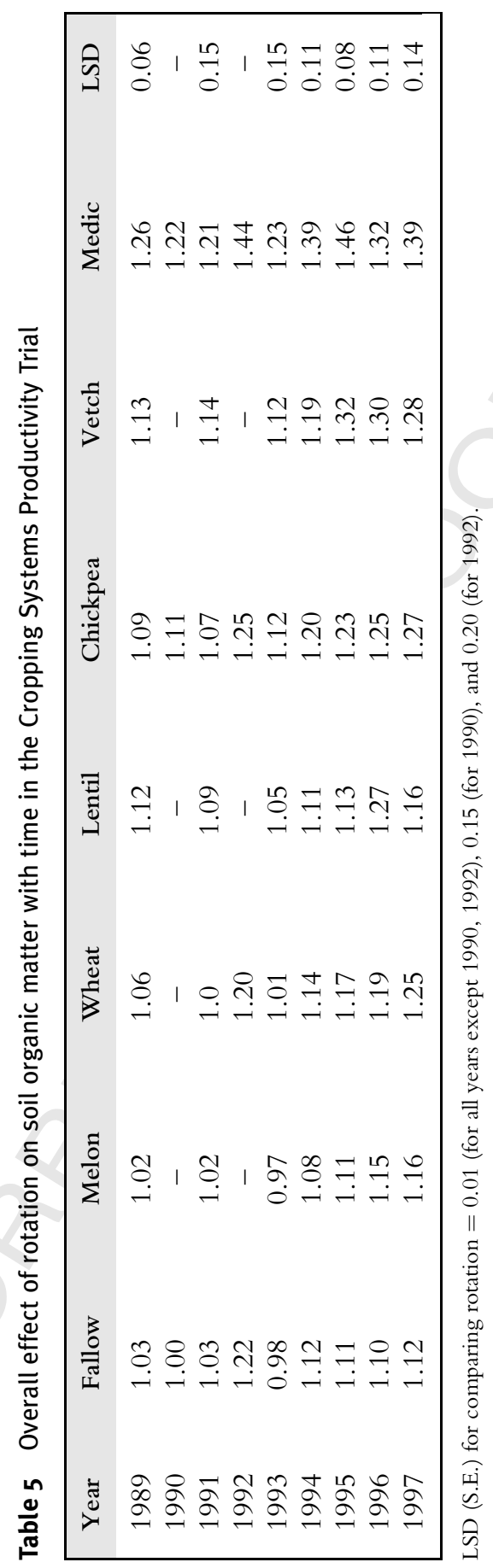


stability and infiltration and hydraulic conductivity in both the laboratory and field. The lowest aggregation percentage and aggregate stability was from the continuous wheat rotation, followed by fallow and melon, while the highest values were from the medic and vetch rotations, with chickpea and lentil being intermediate. Coefficients of dispersion values were inversely related to aggregate stability. Hydraulic conductivity and infiltration values followed the same trend as for aggregate stability. These parameters were closely related to the SOM values in the rotations. However, a subsequent micro-morphological study of soil samples from the rotation, using polarizing thin sections and the scanning electron microscope (Kapur et al., 2007) found the effect of SOM to be less consistent than at the micro-morphological level.

In the latter years of the trial, the dynamic nature of SOM within seasons was examined (Ryan et al., 2008e), along with more reactive labile and biomass carbon fractions. Measurements of SOM within micro-plots in the various rotations decreased consistently from winter to summer, but the levels followed a similar pattern as shown by Masri and Ryan (2006). Thus, the highest levels were with medic and vetch, with fallow being consistently best. While labile $\mathrm{C}$ followed the same pattern as total SOM, biomass $\mathrm{C}$ was much more responsive to environmental conditions, that is, soil moisture and temperature, being lowest in the colder and hot dry periods. The study highlighted the dynamic nature of SOM in soil and its influence by rotations. It also provided an opportunity to study the age of SOM in the trial based on C-14 dating (Jenkinson et al., 1999).

The effect of rotations on SOM was indicated in other trials at ICARDA. In the first 6 years of the grazing trial (L-13), which involved wheat/medic rotation showed an increase in SOM from 0.8 to $1.2 \%$, an effect attributed to root biomass and leaf drop (White et al., 1994). In the fallow rotation, SOM experienced a 14\% decline. Subsequently, the trial was modified too in terms of treatments and barley was substituted for wheat, but still major rotational differences persisted, that is, $0.86 \%$, continuous barley; $1.02 \%$, fallow; $1.23 \%$, medic; and $1.18 \%$, vetch. In a similar rotation where $\mathrm{N}$ had been added to the cereal phase, the respective SOM percentages were 1.01, 1.18, 1.25, and 1.26 (Ryan et al., 2002). In another study on barley, "New Rotation," at both Tel Hadya and the drier site Breda, continuous barley had slightly higher SOM values than fallow, and both were increased by $\mathrm{N}$ and $\mathrm{P}$ fertilization (Ryan, 1998). Therefore, SOM values are influenced by rotations and $\mathrm{N}$ fertilization.

\subsection{Crop water use and water use efficiency}

While modern farming in the Mediterranean region involves chemical inputs and new varieties, the farmer has no control over the low and erratic rainfall, other than to mitigate its effects by irrigation in order to stabilize 
crop yields (Cooper et al., 1987). Within this context, the challenge for research was to incorporate new approaches in existing farming systems in order to maximize the available soil moisture from rainfall, that is, achieving WUE. In its simplest form, WUE represents the ratio of the amount of crop biomass produced (grain, forage, tuber yields) to the amount of water used to produce the crop (i.e., transpiration by the crop plus evaporation from the soil).

Given that water is fundamental to Mediterranean agriculture, it was not surprising that the issue of WUE was the focus of planning workshops in the early years of ICARDA (Monteith and Webb, 1981) and subsequently at the regional (Harris et al., 1991) and international levels (Van Duivenbooden et al., 1999). While other ICARDA workshops focused on fertilizer-use efficiency and soil fertility, it was always in the implicit context of efforts to improve WUE (Ryan, 1997; Ryan and Matar, 1992). With these considerations, WUE was a key issue in ICARDA's long-term trials, even if not specifically stated as such.

While most trials recorded rainfall and related weather data, and thus obtained a crude estimate of WUE, the Cropping Systems Productivity trial (Harris, 1995) was one of the few trials in which detailed measurements of soil water were made throughout the season in the main rotations, using neutron probe measurements, that is, recharge/discharge (Pala et al., 2007). Throughout the 12 years of the trial, depth of the wetting front varied with seasonal rainfall $(214-504 \mathrm{~mm})$. The greatest limitation to growth was the supply of available moisture rather than the moisture-storage capacity as the soils were deep, that is, 1-2 $\mathrm{m}$ and clayey (Ryan et al., 1997). Wheat grain yield was dictated largely by the extent to which alternative or antecedent crop dried out the profile, in addition to the overall influence of seasonal rainfall and its distribution. Chickpea and medic extracted as much water as continuous wheat, but fallow, lentil, watermelon, and vetch left some water (residual moisture) for the succeeding cereal, thus influencing WUE of the rotation for the cereal, which decreased in the following order: fallow, vetch, lentil, medic, chickpea, and continuous wheat. At the system level, the wheat/lentil and wheat/vetch rotations were more efficient in using rainfall for crop growth, producing $27 \%$ more grain than the wheat/fallow rotation which was similar to the wheat/chickpea rotation. The continuous wheat rotation was the least efficient at the individual crop and rotation levels. As $\mathrm{N}$ fertilizer increased cereal growth, the legume/cereal rotations not only are more sustainably productive, but are also the most efficient at using the limited available soil moisture.

The same cropping systems trial was one of three trials where WUE of chickpea and lentil was studied (Zhang et al., 2000) meaning that the ET over the 12 seasons was $268 \mathrm{~mm}$ for chickpea and $259 \mathrm{~mm}$ for lentil, while the depth of water extraction was $120 \mathrm{~cm}$ for chickpea and $40 \mathrm{~cm}$ for lentil. The WUE for dry matter and seed yield for lentil was 13.7 and $3.8 \mathrm{~kg} \mathrm{ha}^{-1}$ 
$\mathrm{mm}^{-1}$, respectively, while the respective values for chickpea were 8.7 and $3.2 \mathrm{~kg} \mathrm{ha}^{-1} \mathrm{~mm}^{-1}$.

A related 5-year study of irrigated and rainfed cropping at Tel Hadya partitioned water use into transpiration and soil evaporation, and calculated WUE and transpiration efficiency as influenced by $\mathrm{N}$ fertilization (Zhang et al., 1998). Nitrogen reduced evaporation from soil from 120 to $101 \mathrm{~mm}$ under rainfed conditions and from 143 to $110 \mathrm{~mm}$ under irrigated conditions. The transpiration increased from 153 to $193 \mathrm{~mm}$ under rainfed conditions and from 215 to $310 \mathrm{~mm}$ under irrigation. Thus, under rainfed conditions $35 \%$ of the ET is lost from the soil surface in fertilized wheat because of early ground cover by more biomass growth; the corresponding figure was $44 \%$ when the crop is unfertilized. The transpiration efficiency for the fertilized wheat was $43.8 \mathrm{~kg} \mathrm{ha}^{-1} \mathrm{~mm}^{-1}$ for dry matter and $15 \mathrm{~kg} \mathrm{ha}^{-1} \mathrm{~mm}^{-1}$ for grain yield. A similar study involving supplemental irrigation, $\mathrm{N}$ fertilization, and sowing dates on wheat over 4 years (Oweis et al., 2000) showed the positive influence of $\mathrm{N}$ in increasing WUE, but delayed sowing decreased it.

While most of the research on WUE was on wheat, we also addressed the issue for barley in the drier rainfall zone in Northern Syria at the Breda (280 mm) experimental station (Harris, 1994). The 10-year trial compared barley/vetch with continuous barley. The barley/vetch rotation, fertilized with $\mathrm{N}$ and $\mathrm{P}$ in the barley phase, produced $0.6-0.9 \mathrm{t} \mathrm{ha}^{-1}$ more biomass than continuous barley, amounting to a $20-30 \%$ increase in WUE. While soil evaporation was about $100 \mathrm{~mm}$ per season, the transpiration efficiency of the fertilized barley was $36.7 \mathrm{~kg} \mathrm{ha}^{-1} \mathrm{~mm}^{-1}$ after vetch and $23.7 \mathrm{~kg} \mathrm{ha}^{-1}$ $\mathrm{mm}^{-1}$ with continuous barley. Various other studies at ICARDA have shown that WUE can also be increased by $\mathrm{P}$ fertilization where soils are responsive to $\mathrm{P}$, and by weed control (Cooper et al., 1987). In essence, any cultural practice that increased yield within any given seasonal rainfall also increased the WUE of the crops in the production system.

\subsection{Phosphorus dynamics in arable soils and rangeland}

Despite the many long-term field studies that examined the implications of changes in fertilizer-applied $\mathrm{P}$ in relation to fertilizer use efficiency in terms of crop yields (e.g., Aulakh et al., 2003; Blake et al., 2000), such studies have been rare in the Mediterranean region. Studies that examined the long-term reactions of $\mathrm{P}$ in soils were mainly laboratory based (Afif et al., 1993; Ryan et al., 1985). Only two such trials were conducted at ICARDA, one dealing with arable cropping and the other on rangeland native pasture.

The cereal-based rotation trial described by Ryan et al. (2008f) was a 9-year study of residual and initially applied $\mathrm{P}\left(0-88 \mathrm{~kg} \mathrm{P} \mathrm{ha}^{-1}\right)$ and yearly additions of $\mathrm{P}\left(0-28 \mathrm{~kg} \mathrm{P} \mathrm{ha}^{-1}\right)$ to the cereal (barley, wheat) phase of the cereal/legume (lentil, chickpea) rotations at three experiment station with varying long-term rainfall $\left(470,342,270 \mathrm{~mm}\right.$ year $\left.{ }^{-1}\right)$. While crop yields 
were more influenced by the annual $\mathrm{P}$ applications, both residual and direct $\mathrm{P}$ influenced Olsen-P values and crop $\mathrm{P}$ uptake. Where no $\mathrm{P}$ was applied each year or the lowest amount applied $\left(7 \mathrm{hg} \mathrm{ha}^{-1}\right)$, the balance between applied $\mathrm{P}$ and crop offtake became increasingly negative. This trend was counterbalanced by the higher direct $\mathrm{P}$ application rates and by residual $\mathrm{P}$. The study showed that $\mathrm{P}$ response is highly variable in rainfed cropping, with rainfall on soil moisture being the dominant influence on yields. Where Olsen $\mathrm{P}$ levels were less than $6 \mathrm{mg} \mathrm{kg}^{-1}$, a response to either cereal or legume is unlikely. The study provided the data for development of a soil-plant P simulation model (Daroub et al., 2003). A shorter field study (5 years) with irrigated corn in neighboring Turkey (Ibrikci et al., 2005) showed that response to $\mathrm{P}$ was influenced by seasonal rainfall, additional to irrigation and that residual levels of $\mathrm{P}$ can build up quickly despite initial deficient levels.

The multiyear studies of $\mathrm{P}$ use on rangelands involved sown pasture and native pasture. The sown-pasture trial (4 years) of Osman and Cocks (1992) involved seeding of annual legumes (subterranean clover and Medicago rigidula) followed by topdressing with superphosphate. While the exotic species introduced were unable to compete with native grasses, the success of both $\mathrm{P}$ and such legumes depended on partial protection from grazing, leading to a buildup of the seed bank. The 12-year trial of Osman (1997) with native pasture or marginal land showed that annual application of $\mathrm{P}$ $\left(5,10 \mathrm{~kg} \mathrm{P} \mathrm{ha}^{-1}\right)$ for 7 years consistently increased herbage production each year, and increased with seasonal rainfall, and resulted in increased sheep production. The $\mathrm{P}$ fertilization changed the botanical composition toward more nutritious forage legumes. Even after P fertilization was discontinued, the effect on yield and botanical composition persisted as did the available P levels.

\subsection{Economic assessment}

In comparison with biophysical measurements, economic evaluation of long-term cropping systems trial was comparatively neglected. However, preliminary economic considerations were applied to the data from the Cropping Systems Productivity trial (Rodriguez et al., 1999). Gross margins varied widely with the rotations, being highest for the vetch rotation and lentil and least for continuous wheat, with fallow and melon (equivalent to fallow in this study) slightly better than continuous wheat. Responses to $\mathrm{N}$ were economical in all rotations except the medic as it contributed adequate $\mathrm{N}$ through biological $\mathrm{N}$ fixation. Gross margins in all rotations were reduced in dry years, while rainfall increased the economic response to $\mathrm{N}$ fertilizer. The essential economic value for the forages, vetch and medic, lay in their substitution for stored grain, concentrates or straw that would 
otherwise have to be bought. Economic assessment of grain crops in the rotation is simpler than with forage crops and involving the grazing animal.

Using data from the wheat-based grazing trial (L-13), Petersen et al. (2002) attempted to develop a whole-farm economic model that included market and farmer surveys for the same years. This model showed that improvements in wheat grain yield have the greatest effect on increasing incomes, with improvements in lentil grain yields ranking second. A related study of the same trial (Nordblom et al., 1994) showed that at prevailing prices and yields from the trial, medic was less profitable than the traditional rotations. These authors concluded that farm size had a determining influence on profitability. Where labor is cheap and plentiful on small holdings, labor-intensive rotations are likely to be more profitable, while the reverse is true for larger holdings. More rigorous economic analyses are needed for both barley- and wheat-based rotation trials at ICARDA-and indeed throughout the region as a whole.

\section{Statistical Trends in Crop Rotations}

As has been shown from this overview of rotations in the Mediterranean region, continuous cropping or mono-cropping, particularly of cereals, leads to yield decline due to build up of unfavorable factors. An appropriately selected sequence of crops, for example, cereal followed by legumes, provides a natural control of yield limiting factors such as diseases and pests, and deterioration of soil fertility. Therefore, crop rotation (repetition of a sequence of crops on the same piece of land) provides a mechanism for sustainable crop production. Some of the issues associated with crop rotation research from the statistical perspective include evaluation of crop rotations and associated agronomic inputs in short-term productivity, and yield trends in the short and long terms. Annual crop productivity trends over time are measures of sustainability of the system under evaluation. The statistical literature on design and analysis crop rotation trials is extensive (e.g., Preece, 1986; Rowell and Walters, 1976).

Challenges arise from the experimental designs, and the nature of the response in association with time and space. The experimental design must ensure that each phase of the crop rotation appears each year to allow for capturing the exposure to annual climatic variation. In crop rotation trials, the plots are measured over time, therefore, the observations arising from the same plot are likely to be correlated. Furthermore, spatial variability is a reality in field trials. Thus, any attempt to evaluate crop rotations along with agronomic inputs must take into account-not ignore-the due dependence of experimental errors. Attempts made in this direction are reviewed. 


\subsection{Estimation of time trends}

The conduct and maintenance of long-term trials takes considerable resources, and it takes time for treatments to show differential effects. Changes in yields with time have been addressed by several researchers including Barnett et al. (1994), Jenkinson et al. (1994), Guertal et al. (1994) from various perspectives. While time-trend estimation based on polynomial contrasts are worthwhile in the case of long series, where the plausible rainfall distribution would have been captured by the crop sequences in rotation, it is very important to detect significant trends in the short term. Using a linear model for crop yield in time with due accounting for the effects of rainfall and planting date, models were developed for estimating time trends and statistical formulas were developed for the time to detect significant trends, for evaluating fertilizer inputs in continuous barley cropping (Singh and Jones, 1997), and fertilizer regimes in 2-course barley/ legume rotations (Jones and Singh 2000a; Singh and Jones, 2002). In these models, errors arising over time from the same plot were assumed to follow a first-order autocorrelation. No attempt was made to examine suitability of such an assumption on pattern of dependence of errors.

In the productivity and long-term time-trend evaluation of 2-course barley rotations and continuous barley, Singh et al. (1996) screened a number of covariance structures in temporal errors. Singh and Jones (2002) used the Akaike Information Criterion (AIC), a function of penalized log-likelihood, for selecting the best covariance structure out of the five most likely structures for plot covariances. For the 14-year data on grain and straw yields from 2-course barley/legume rotations (Barley-Pea/ Lathyrus, Barley/Vetch, Barley/Fallow, and Barley/Barley) and two fertility regime (fertilized and unfertilized plots in barley phase) at the two contrasting rainfall sites (Tel Hayda and Breda), the most appropriate covariance structure was that where the plot errors had heterogeneous variances and constant correlation between cycles of rotation.

Using such a covariance structure, evaluation of data showed that the legume rotations gave (1) higher productivity as well as (2) higher annual increases (time trend) compared with the continuous barley system. These methods take into account dependence of plot errors over time; however, they ignore any likely spatial variability present in the trial layout. Thus, statistical methods are needed to evaluate crop rotations under a chosen temporal and spatial covariance structure of plot errors.

Singh and Jones (2002) modeled 10-year data sets from two monocropped barley trials and screened a set of 24 plausible structures in three dimensions (two dimensions for the space and one for the time). The most appropriate covariance structure showed the presence of autocorrelations in spatial and temporal dimensions, and improved significance of the fertilizer effect and the interaction with year in comparison with an assumed 
structure-based independence of errors. This study estimated the time trends by (a) accounting the seasonal variable contribution in annual variability for short data series and (b) using the linear component of the orthogonal polynomial for long series. Compared with the model with assumed independence of temporal errors, time-trend detection was found more powerful for the short data series. Further when the seasonal variables were accounted, the estimates of yield trends for fertilizer application were numerically greater than when estimated from linear contrast, reflecting the substantial role of seasonal variations.

The challenge of modeling temporal and spatial errors and carrying out associated analysis for the data from crop rotation trials, where models should allow scope for estimating residual effects of various phases of rotation. The approach of Singh and Jones (2002) was limited to crop yields but could easily be extended for detecting trends in soil parameters as well, and any possible interrelationship between the sets of crop and soil parameters.

\section{LESSONS LEARNED}

As in any form of experimentation, in retrospect there are always things that one might not have done or would have done different or done earlier. Indeed, the fundamental principles underlying long-term crop rotation trials were well known (Preece, 1986), while specific pitfalls of such trials in a Mediterranean environment under rainfed cropping conditions were highlighted (Keatinge and Somel, 1993). The following is listing of such examples of hindsight.

- Though many trials were conducted in the WANA region, there seems to have been little collaboration or coordination between the various staff from the national programs that conducted the trials, other than reporting results at various workshops and meetings (Harris et al., 1991; Ryan, 1997). Such collaboration might have enhanced the research approach and given added value to impact at farm level. As networks were used effectively at ICARDA in different areas (Ryan et al., 1995), there was no specific network devoted to long-term trials.

- Some major long-term trial that involved many partners and institutions failed to comply with the research protocol and produced no significant published results as a result of lack of sufficient coordination between institutions with no overall consistent authority or coordinator.

- Though ICARDA had supported some long-term trials in some countries of the region, they were soon phased out as there was not sufficient commitment from the particular national program.

- At ICARDA, the number of long-term trials was excessive given the resources of finance and personnel needed to conduct such trials. In 
addition, many of the trials were overlapping in terms of their objectives. A few well-planned, well-managed, and longer trials would have been better.

- Many of the trials were not planned as long term and others were associated with one scientist and were terminated when that person left. All such trials should involve scientists from various disciplines and support staff and should have an in-built mechanism for continuity regardless of personnel departure.

- Ideally, an international center is well suited to conducting long-term trials and has a comparative advantage relative to the national programs. As such, they have the resources to plan such trials for the long term. Yet, most trials were terminated in response to a temporary restriction in the institution's funding without realizing their full potential.

- Some trials were exclusively focused on grain and straw yield and did not exploit related areas of research such as soil biology and physical properties, as well as nutrient dynamics. A systems approach would have been preferred.

- As significant as SOM is, measurements of this property were rudimentary and limited. In the Cropping Systems Productivity trial, it was several years before any measurements at all were taken.

- Despite a workshop held prior to the initiation of long-term trial that recommended baseline soil analyses in all trials, this recommendation was not generally adhered to.

- In some trials, the site was too variable in terms of soil properties that influenced crop growth and water use, for example, variable soil depth.

- One trial in particular had plot sizes that were too small for multiyear experimentation, particularly as it involved rhizobia and biological $\mathrm{N}$ fixation, possibly leading to cross contamination.

- In some cases, the cereal in question was inappropriate. One trial, mainly emphasizing grazing management initially began with wheat overlapping with another trial, and later switched to barley, which was more appropriate. In such grazing trial, reliable estimates of biomass growth were not taken to complement the offtake in animal weight gain. Although cages for biomass sampling in grazed plots were installed, they were neglected and yielded nothing.

- In the Cropping Systems Productivity trial, some treatments should not have been included. For instance, using watermelon as a summer crop was unsuccessful as it was only possible to grow it in only 4 of the 14 years due to insufficient carryover soil moisture. Similarly, there was little point in having a poorly quantifiable "medium" stubble grazing treatment.

- As some crops in the rotation were known to behave similarly, the number of crops involved could have been reduced, for example, one food legume, chickpea or lentil, and only one forage, vetch or medic. In hindsight, medic might have not been included as it was not likely to be adopted as a self-regenerating pasture in the Mediterranean region (Christiansen et al., 2000) despite its success in Australia. 
- While some trials had revealed consistent information with respect to crop yields, but as the Cropping Systems Productivity trial was beginning to show trends with respect to SOM, it should have been continued until a clear equilibrium level was identified for the overall environment and the particular cropping system. This information would have been crucial in the area of carbon sequestration.

- Given the cyclical rainfall and moisture patterns in a Mediterranean climate, only limited research was done on seasonal nutrient dynamics.

- There was insufficient coordination and sharing of information on the trials, they would have benefited from regular revisions and assessments.

- As long-term trials are a valuable storehouse of data for modeling and prediction of future trends, such data should be screened for reliability.

\section{Future Strategies}

Long-established and continuing long-term cropping systems field experiments have proven invaluable in assessing the sustainability of agroecosystems (Johnston, 1997). Given the costs of running the experiments, the question of diminishing returns to science and their relevance to modern conditions inevitably arises (Johnston, 1997). However, considerable thought has to be put into terminating any long-term trial or marking any substantial modification in it. Whether long-term trials with fixed parameters are flexible enough for a rapidly changing agriculture is debatable, key factors essential for long-term trials are adequate funding, security of tenure, and institutional commitment to run trials for a planned length of time. The absence of any of these conditions helps explain the short-lived, multiyear agronomic system trials in the Mediterranean region (Steiner and Herdt, 1993).

Despite having relatively favorable conditions for the establishment and maintenance of long-term trials, as an international research center ICARDA was unable to continue most of its long-term trials largely because of funding restrictions, changing scientific personnel, and shifting emphasis in agricultural research from traditional areas such as agronomy and soil fertility to biotechnology, gender issues, and farmer participatory approaches. Long-term agronomy trials were seen as having little relevance to CGIAR Centers' goal of poverty alleviation. While the many limited-duration trials yielded valuable crop yields data, the scientific potential of most trials was not reached. Is there any further need for long-term trials and if not what is going to replace them? While the contributions of legumes in the rotation as a substitute for fallow or continuous cropping has been established in terms of sustainable yields and maximized WUE, there is need for a few well-planned regional ecosystem trials that would examine the implications of cropping 
systems on $\mathrm{C}$ sequestration and thus establish the equilibrium levels attainable under such conditions. Similarly, greater long-term trial attention should be focused on conservation tillage and zero-till direct sowing systems for energy, and water use efficiency and $\mathrm{C}$ sequestration.

In attempting to foster a new paradigm as a replacement for the traditional long-term agronomic trials, with strategic and basic objectives, Jones $(2000 \mathrm{a}, \mathrm{b})$ introduced the notion of "anticipatory long-term research" for sustainable productivity. In his opinion, the concept "involves a holistic approach, building a longer view and a greater dynamism into traditional agronomy, enhancing ties to socioeconomic and resource management disciplines, and reconciling the demand for high-yielding technology with the strategic issues of sustainable production." Jones called for a research approach that balances present and future priorities according to a more holistic understanding of short- and long-term processes in the production environment. In essence, what is involved is maintaining a body of strategic research embracing short-term studies within the long-term framework. With such studies, likely problems that are to emerge at farm level are addressed.

\section{ACKNOWLEDGMENTS}

While many people were involved in the planning and operation of the various trials described here, it would not be possible to thank them all for their contributions, but we are indebted to all who contributed in any way. However, it would be remiss not to recognize the enormous contributions of Dr. Hazel Harris who was the driving force behind the Cropping Systems Productivity trial and Dr. Mike Jones who spearheaded the work on barley. Similarly, Mr. Samir Masri played an invaluable support role in many of the trials mentioned here. We are grateful to him, and as he passed away suddenly last year, we treasure his memory.

\section{REFERENCES}

Abdel Monem, M. A. S. (1986). Labelled urea fertilizer experiments on arid soils of the Mediterranean region. PhD Dissertation, Colorado State University, Fort Collins, CO, USA.

Abo Elenein, R. A., Abdel Shafi, A., Abdel Monem, M., Kamel, A., Solh, M. B., Bedier, M., and Khalifa, H. (2000). A new research paradigm for sustainability research in Egypt. Expl. Agrc. 33, 265-271.

Afif, E., Matar, A., and Torrent, J. (1993). Availability of phosphate applied to calcareous soil of West Asia and North Africa. Soil Sci. Soc. Am J. 57, 756-760.

Aulakh, M., Kabba, B. S., Baddesha, H. S., Bahl, G. S., and Gill, M. P. S. (2003). Crop yields and phosphorus transformation after 25 years of applications to a sub-tropical soil under groundnut-based cropping systems. Field Crops Res. 83, 283-286.

Avcin, A., and Avci, M. (1992). Soil water and inorganic nitrogen accumulation at sowing time of wheat in two-year rotation as influenced by pervious crops under Central Anatolian 
conditions. In "Fertilizer Use Efficiency under Rainfed Agriculture in West Asia and North Africa" (J. Ryan and A. Matar, Eds.), pp. 64-70. Proceedings of the Fourth Regional Workshop, 5-10 May 1991, Agadir, Morocco, ICARDA, Aleppo, Syria.

Barnett, V., Landau, S., and Welham, S. J. (1994). Measuring sustainability. Envron. Ecol. Stat. 1, 21-36.

Bessam, F., and Mrabet, R. (2003). Long-term changes in soil organic matter under conventional tillage and no-tillage systems in semi-arid Morocco. Soil Use Manage. 19, 139-143.

Blake, L., Mersick, S., Koerchens, M., Moshal, S., Poulton, P. R., Goulding, K. W. T., Weigel, A., and Paulson, D. S. (2000). Phosphorus content in soil, uptake by plants, and balance in three European long-term field experiments. Nutr. Cycl. Agroecosyst. 56, 263-275.

Borlaug, N. E. (2003). Feeding a world of 10 billion people: The TVA/IFDC Legacy. Travis P. Hignett Memorial Lecture, March 14, 2003. Muscle Shoals, AL, USA.

Bouzza, A. (1990). Water conservation in wheat rotations under several management and tillage systems in semiarid areas. Ph.D. Dissertation, University of Nebraska, Lincoln, NE, USA.

Cakmak, I. (1998). Selection and characterization of cereal genotypes with high zinc efficiency and evaluation of bioavailability of zinc in wheat for the Central Anatolia Region. Nato-Science for Stability Programme, pp. 171. Kemal Printing Co., Adana, Turkey.

Christiansen, S., Bounejmate, M., Sawny-Edo, H., Mawlawi, B., Shomo, F., Cocks, P. S., and Nordblom, T. (2000). Tah village project Syria: Another unsuccessful attempt to introduce ley farming in the Mediterranean basin. Expl. Agric. 36, 181-193.

Cooper, P. J. M., Gregory, P. J., Tully, D., and Harris, H. C. (1987). Improving water-use efficiency of annual crops in the rainfed forming systems of West Asia and North Africa. Expl. Agric. 23, 113-158.

Damania, A. B., Valkoun, J., Willcox, G., and Qualset, C. O. (Eds.) (1998). The origins of agriculture and crop domestication. International Center for Agricultural Research in the Dry Areas, Aleppo, Syria. Proceeding of the Harlan Symposium, May 10-14, 1997.

Daroub, S. H., Gerakios, A., Ritchie, J. T., Freisen, D. K., and Ryan, J. (2003). Development of a soil-plant phosphorus simulation model for calcareous and weathered tropical soils. Agric. Syst. 76, 1157-1181.

Dregne, H. E. (2006). Historical perspectives. In "Dryland Agriculture" (G. A. Peterson, P.W. Unger, and W.A Payne, Eds.), pp. 27-38. Agron. Monograph No. 23, Am, Soc. Agron., Crop Sci. Soc. Am., Madison, WI, USA.

FAO. (2002). World agriculture: Towards 2015/2030. Summary report. Food and Agriculture Organization of the United Nations, Rome, Italy.

Garabet, S., Wood, M., and Ryan, J. (1998). Nitrogen and water effects on wheat yield in a Mediterranean-type climate. I. Dry matter yield and nitrogen accumulation. Field Crops Res. 57, 309-318.

Gibbon, D. (1981). Rainfed systems in the Mediterranean region. Plant Soil 58, 39-80.

Guertal, E. A., Raun, W. R., Westerman, R. L., and Boman, R. K. (1994). Applications of stability analyses for single-site, long-term experiments. Agron. J. 86, 1016-1019.

Harlan, J. R. (1992). “Crops and Man,”, 2nd ed. pp. 284. Am. Soc. Agron., Crop Sci. Soc. Am., Madison, WI, USA.

Harmsen, K. (1984). Nitrogen fertilizer use in rainfed agriculture. Fert. Res. 5, 371-382.

Harris, H. C. (1994). Water-use efficiency of crop rotations in a Mediterranean environment. Aspects Appl. Biol. 38, 165-172.

Harris, H. C. (1995). Long-term trials on crop and soil management at ICARDA. Adv. Soil. Sci. 19, 447-469. 
Harris, H. C., Cooper, P. J. M., and Pala, M. (1991). Soil and crop management for improved water use efficiency in rainfed areas. In "Proceedings of an International Workshop Held in Ankara, Turkey, May 15-19, 1989. International Center for Agricultural Research in the Dry Areas, Aleppo, Syria, ICARDA, Aleppo, Syria.

Harris, H. C., Ryan, J., Treacher, T. T., and Matar, A. (1995). Nitrogen in dryland farming systems common in northwestern Syria. In "Livestock and Sustainable Nutrient Cycling in Mixed Farming Systems of Sub-Saharan Africa” (J. M. Powell, S. Femandez-Rivera, T. O. Williams, and C. Renard, Eds.), pp. 323-335. International Livestock Center for Africa, Addis Ababa, Ethiopia.

Ibrikci, H., Ryan, J., Ulger, A. C., Buyuk, G., Cakir, B., Korkmaz, K., Karnez, E., Ozgenturk, G., and Konuskan, O. (2005). Maintenance of phosphorus fertilizer and residual effect on corn production. Nutr. Cycl. Agroecosyst. 72, 279-286.

Jenkinson, D. J. (1991). The Rothamsted long-term experiments: Are they still of use? Agron. J. 83, 2-10.

Jenkinson, D. S., Potts, J. M., Perry, J. N., Barnett, V., and Coleman, K. (1994). Trends in herbage yields over the last century on the Rothamsted long-term continuous hay experiment. J. Agric. Sci. Camb. 122, 365-374.

Jenkinson, D. S., Harris, H. C., Ryan, J., McNeill, A., Pilbearn, C. J., and Coleman, K. (1999). Organic matter turnover in a calcareous clay soil from Syria under a two-course cereal rotation. Soil Biol. Biochem 31, 687-693.

Johnston, A. E. (1997). The value of long-term field experiments in agricultural, ecological, and environmental research. Adv. Agron. 59, 291-333.

Johnston, A. E., and Powlson, D. (1994). The setting-up, conduct and applicability of longterm, continuing field experiments in agricultural research. In "Soil Resilience and Sustainable Land Use" (D. J. Greenland, and I. Szabolics, Eds.), pp. 355-421. CAB International, Wallingford, Oxfordshire, UK.

Jones, M. J. (1993). Sustainable agriculture: An explanation of a concept. In "Crop Protection and Sustainable Agriculture", pp. 30-47. John Wiley, Chichester, UK.

Jones, M. J. (1997). The challenge of production system sustainability: Long-term studies in agronomic research in dry areas. International Center for Agriculture Research in the Dry Areas, Aleppo, Syria.

Jones, M. J. (2000a). Anticipatory long-term research for sustainable productivity. Expl. Agric. 36, 137-150.

Jones, M. J. (2000b). Comparison of conservation tillage systems in barley-based cropping systems in northern Syria. Expl. Agric. 36, 15-26.

Jones, M. J., and Singh, M. (1995). Yields of crop dry matter and nitrogen in long-term barley rotation trials at two sites in northern Syria. J. Agric. Sci. Camb. 124, 389-402.

Jones, M. J., and Singh, M. (2000a). Long-term yield patterns in barley based cropping systems in northern Syria. 1. Comparison of rotations. J. Agric. Sci. Camb. 135, 223-236.

Jones, M. J., and Singh, M. (2000b). Long-term yield patterns in barley-based cropping systems in northern Syria. 2. The role of feed legumes. J. Agric. Sci. Camb. 135, 237-249.

Jones, M. J., and Singh, M. (2000c). Long-term yield patterns in barley-based cropping systems in northern Syria. 3. Barley monocropping. J. Agric. Sci. Camb. 135, 251-259.

Jones, M. J., and Wahbi, A. (1992). Site-factor influence on barley response to fertilizer in on-form trials in northern Syria: Description and predictive models. Expl. Agric. 28, 63-87.

Kacemi, M. (1992). Water conservation, crop rotations, and tillage systems in semiarid Morocco. Ph.D. Dissertation, Colorado State University, Fort Collins, CO, USA.

Kapur, S., Ryan, J., Akca, E., Celik, I., Paglai, M., and Tulun, Y. (2007). Influence of Mediterranean cereal-based rotations on soil micromorphological characters. Geoderma $142,318-324$. 
Karaca, M., Guler, M., Durutan, N., Meyveci, K., Avci, M., Eyubodly, H., and Avcin, A. (1989). Effect of rotation systems on wheat yield and water use efficiency in dryland areas of Central Anatolia. In "Proceedings of the Workshop on Soil and Crop Management for Improved Water Use Efficiency in Rainfed Areas" (H. C. Harris, P. J. M. Cooper, and M. Pala, Eds.), pp. 251-259. ICARDA, Aleppo, SyriaMay 15-19, Ankara, Turkey.

Karlen, D. L., Varvel, G. E., Bullock, D. G., and Cruse, R. H. (1994). Crop rotations for the 21st century. Adv. Agron. 53, 1-45.

Kassam, A. H. (1981). Climate, soil and land resources in North Africa and West Asia. Plant Soil 58, 1-29.

Keatinge, J. D. H., and Somel, K. (1993). Guidelines for improved agronomic management and economic evaluation of crop rotation trials in Mediterranean environments. Expl. Agric. 29, 437-447.

Keatinge, J. D. H., Chapanian, N., and Saxena, M. C. (1988a). Effect of improve management of legumes in a legume-cereal rotation on field estimates of crop nitrogen uptake and symbiotic nitrogen fixation in northern Syria. J. Agric. Sci. Camb. 110, 651-659.

Keatinge, J. D. H., Dennett, M. D., and Rogers, J. (1985). The influence of precipitation regime on the management of three course crop rotations in northern Syria. J. Agric. Sci. Camb. 104, 281-287.

Keatinge, J. D. H., Dennett, M. D., and Rodgers, J. (1988b). The influence of precipitation regime on the crop management of dry areas in northern Syria. Field Crops Res 13, 229-249.

Khan, Z. D., Ryan, J., and Berger, K. C. (1979). Available boron in calcareous soils of Lebanon. Agron. J. 70, 79-82.

Lal, R. (1987). Managing the soils of Sub Saharan Africa. Science (Washington, DC). 236, 1069-1076.

Lal, R. (2001). Managing world soils for food security and environment quality. Adv. Agron. 74, 157-192.

Lal, R. (2002). Carbon sequestration in dryland ecosystems of West Asia and North Africa. Land Degrad. Dev. 13, 45-59.

Masri, Z., and Ryan, J. (2006). Soil aggregation and related physical properties in a Mediterranean wheat-based, long-term rotation trial. Soil Tillage Res. 87, 146-154.

Matar, A., Torrent, J., and Ryan, J. (1992). Soil and fertilizer phosphorus and crop responses in the dryland Mediterranean zone. Adv. Soil. Sci. 18, 82-146.

Materon, L., and Ryan, J. (1995). Rhizobial in ovulation and phosphorus and zinc nutrition for annual medics (Medicago spp.) adapted to Mediterranean-type environment. Agron.J. 87, 692-698.

McNeill, A. M., Pilbeam, C. J., Harris, H. C., and Swift, R. S. (1996). Seasonal variation in the sustainability of different methods for estimating biological nitrogen fixation by grain legumes under rainfed conditions. Aust. J. Agric. Res. 47, 1061-1073.

McNeill, A. M., Pilbeam, C. J., Harris, H. C., and Swift, R. S. (1998). Use of residual fertilizer ${ }^{15} \mathrm{~N}$ in soil for isotopic dilution estimates of $\mathrm{N}_{2}$ fixation by grain legumes. Aust. J. Agric. Res. 49, 821-828.

Mikhail, A., Ryan, J., and Nachit, M. M. (2008). Nitrogen fertilization and supplemental irrigation in relation to yield and quality of wheat varieties in Syria. Iran. J. Sci. Technol. (submitted).

Mitchell, C. C., Westernan, R. L., Bram, J. R., and Peck, T. R. (1991). Overview of longterm agronomic research. Agron. J. 83, 24-29.

Monteith, J., and Webb, C. (1981). Soil water and nitrogen in Mediterranean-type environments. Dev. Plant Soil Sci. 1. Martinus Nijhoff/ Dr. W. Junk Puk., The Hague, The Netherlands.

Mrabet, R. (1997). Crop residue management and tillage systems for water conservation in a semiarid area of Morocco. Ph.D. Dissertation. Colorado State University, Fort Collins, CO, USA. 
Mrabet, R., Saber, N., El-Brahli, A., Lahlou, S., and Bessam, F. (2001). Total, particulate organic matter and structural stability of a Calcixerall soil under different wheat rotations and tillage systems in a semi-arid area of Morocco. Soil Tillage Res. 57, 225-235.

Nordblom, T., Pannell, D. J., Christiansen, S., Nersoyan, N., and Bahhady, F. (1994). From weed to wealth? Prospects for medic pastures in the Mediterranean farming system of north-east Syria. Agric. Econ. 11, 29-42.

Orphanos, P. I., and Metochis, C. (1994). The water relation of barley grown continually or after fallow under semi-arid conditions. Expl. Agric. 30, 431-439.

Osman, A. E. (1997). Potential benefits of phosphorus fertilizer on marginal lands. In "Accomplishments and Future Challenges in Dryland Soil Fertility Research in the Mediterranean Area” (J. Ryan, Ed.). ICARDA, Aleppo, Syria, and IMPHOS, Casablanca, Morocco.

Osman, A. E., and Cocks, P. S. (1992). Prospects for improving Mediterranean grasslands in Lebanon through seeding, fertilization, and protection from grazing. Expl. Agric. 28, 461-471.

Oweis, T., Pala, M., and Ryan, J. (1998). Stabilizing rainfed wheat yields with supplemental irrigation in the Mediterranean region. Agron. J. 90, 187-196.

Oweis, T. O., Zhang, H., and Pala, M. (2000). Water-use efficiency of rainfed and irrigated bread wheat in a Mediterranean environment. Agron. J. 92, 231-238.

Pala, M., Matar, A., and Mazid, A. (1996). Assessment of the effects of environmental factors on the response of wheat to fertilizer in on-form trials in a Mediterranean-type environment. Expl. Agric. 32, 339-349.

Pala, M., Harris, H. C., Ryan, J., Makboul, R., and Dozom, S (2000). Tillage systems and stubble management in a Mediterranean-type environment in relation to crop yield and soil moisture. Expl. Agric. 36, 223-242.

Pala, M., Ryan, J., Mazid, A., Abdullah, O., and Nachit, M. (2004). Wheat farming in Syria: An approach to economic transformation and sustainability. Review. Agric. Food Systems 19, 30-34.

Pala, M., Ryan, J., Zhang, H., Singh, M., and Harris, H. C. (2007). Crop water-use efficiency of wheat-based rotation systems in a Mediterranean environment. Agric. Water Manage. 93, 136-144.

Pala, M., Ryan, J., Diekmann, J., and Singh, M. (2008). Barley and vetch yields from dryland rotations with varying tillage and residue management under Mediterranean conditions. Expl. Agric. (in press).

Papastylianou, I. (1993). Productivity and nitrogen fertilizer requirements of barley in rotation systems in rainfed Mediterranean conditions. Eur. J. Agron. 2, 119-129.

Papastylianou, I. (1997). Soil nitrate test for nitrogen recommendations for rainfed barley. In "Accomplishments and Future Challenges in Dryland Soil Fertility Research in the Mediterranean Area" (J. Ryan, Ed.), pp. 238-247. ICARDA, Aleppo, Syria, and IMPHOS, Casablanca, Morocco.

Petersen, E. H., Pannell, D. J., Nordblom, T., and Shomo, F. (2002). Potential benefits from alternative areas of agricultural research for dryland farming in Northern Syria. Agric. Syst. 72, 93-108.

Peterson, G. A., Unger, P. A., and Payne, W. A. (2006). Dryland agriculture Agron. Monograph No. 23. Am. Soc. Agron., Crop. Sci. Soc. Am., Madison, WI, USA.

Pilbeam, C. J. (1996). Effect of climate on the recovery in crop and soil of ${ }^{15} \mathrm{~N}-$ labbled fertilizer applied to wheat. Fert. Res. 45, 209-215.

Pilbeam, C. J., and Hutchison, D. (1998). Fate of nitrogen applied in different fertilizers to the surface of a calcareous soil in Syria. Nutr. Cycl. Agroecosyst. 52, 55-60.

Pilbeam, C. J., McNeill, A. M., Harris, H. C., and Swift, R. S. (1997a). Effect of rotation on the recovery of ${ }^{15} \mathrm{~N}$-labbled fertilizer applied to wheat grown in northern Syria. J. Agric. Sci. Camb. 129, 397-407. 
Pilbeam, C. J., McNeill, A. N., Harris, H. C., and Swift, R. S. (1997b). Effect of fertilizer rate and form on the recovery of ${ }^{15} \mathrm{~N}$-labelled fertilizer applied to wheat in Syria. J. Agric. Sci., Comb. 128, 415-424.

Preece, D. A. (1986). Some general principles of crop rotation experiments. Expl. Agric. 22, 187-198.

Rashid, A., and Ryan, J. (2008). Micronutrient constraints to crop production in the Near East. In "Micronutrient Deficiencies in Global Crop Production" (B. A. Alloway, Ed.), pp. 149-180. Springer, Dordrecht, The Netherlands.

Rashid, A., Rafique, E., and Bughio, N. (1994). Diagnosing boron deficiency in rapeseed and mustard by plant analysis and Soil testing. Commun. Soil Sci. Plant Anal. 25, 2883-2897.

Rasmussen, P. E., and Collins, H. P. (1991). Long-term aspects of tillage, fertilizer and crop residue on soil organic matter in temperate semi-arid regions. Adv. Agron. 45, 93-134.

Rasmussen, P. E., Goulding, K. W. T., Brown, J. R., Grace, P. R., Henry Janzen, H., and Korchens, M. (1998). Long-term agroecosystem experiments: Assessing agricultural sustainability and global change. Science 282, 893-896.

Reeves, D. W. (1997). The role of soil organic matter in maintaining soil quality in continuous cropping systems. Soil Tillage Res. 43, 131-167.

Rodriguez, A., Pala, M., Ryan, J., and Harris, H. (1999). ICARDA's long-term cropping systems trial: An economic assessment, p. 159. Agron. Abstracts, Am. Soc. Agron., Madison, WI, USA.

Rowell, J. G., and Walters, D. E. (1976). Analyzing data with repeated observations on each experimental unit. J. Agric. Sci. Camb. 87, 423-432.

Rosegrant, M. W., Cai, X., and Cline, S. A. (2002). World water and food to 2025, dealing with scarcity. Int. Food Policy Res. Inst., Washington, DC.

Ryan, J. (1997). Accomplishments and future challenges in dryland soil fertility research in the Mediterranean region. ICARDA, Aleppo, Syria, and IMPHOS, Casablanca, Morocco.

Ryan, J. (1998). Changes in organic carbon in long-term rotation and tillage trials in northern Syria. In "Management of Carbon Sequestration in Soil" (R. Lal, J.M Kimble, R.F Follett, and B.A Stewart, Eds.), pp. 285-296. Adv. Soil. Sci. CRC Press, Boca Raton, FL, USA.

Ryan, J. (2002a). Desert and dryland development: Challenges and potential in the new millennium proceedings of the "6th International Conference on the Development of Dry Lands," Aug. 22-27, 1999, Cairo, Egypt, 655 pp. International Center for Agricultural Research in the Dry Areas, Aleppo, Syria.

Ryan, J. (2002b). Available soil nutrients and fertilizer use in relation to crop production in the Mediterranean area. In "Soil Fertility and Crop Production" (K. R. Krishna, Ed.), pp. 213-246. Science Publ., Inc., Enfield, New Hampshire, New York, USA.

Ryan, J. (2004). Soil fertility enhancement in Mediterranean-type dryland agriculture: A perspective for development. In "Challenges and Strategies of Dryland Agriculture" (S. Rao, and J. Ryan, Ed.), pp. 243-256. Crop Science Society of America Special Publication No. 32. Madison, WI, USA.

Ryan, J., and Abdel Monem, M. (1998). Soil fertility management for sustained production in the West Asia-North Africa Region: Need for long-term research. In "Soil Quality and Agriculture Sustainability" (R. Lal, Ed.), pp. 155-174. Ann Arbor Press, Chelsea, MI, USA

Ryan, J., and Matar, A. (1992). Fertilizer use efficiency under rainfed agriculture in West Asia and North Africa. ICARDA, Aleppo, Syria.

Ryan, J., and Pala, M. (2007). Syria's long-term rotation and tillage trials: Potential relevance to carbon sequestration in Central Asia. In "Carbon Sequestration in Central Asia" (R. Lal, Ed.), pp. 223-234. Taylor \& Francis, Leiden, The Netherlands. 
Ryan, J., Hassan, H. M., Bassiri, M., and Tabbara, H. S. (1985). Availability and transformation of applied phosphorus in calcareous soils. Soil Sci. Soc. Am. J. 51, 1215-1220.

Ryan, J., Abdel Monem, M., and El-Gharous, M. (1990). Soil fertility assessment at experimental stations in Chaouia, Abda, and Doukkala. Al-Awamia. 73, 1-47.

Ryan, J., Materon, L., and Christensen, S. (1995). The networks for research collaboration in the dryland west Asia-North Africa region. J. Nat. Resour. Life Sci. Educ. 24, 155-160.

Ryan, J., Masri, S., Garabet, S., Diekmann, J., and Habib, H. (1997). Soils of ICARDA's agricultural experiment stations and sites: Climate, classification, physical and chemical properties, and land use. Technical Bulletin, pp. 107. International Center for Agricultural Research in the Dry Areas, Aleppo, Syria.

Ryan, J., Masri, S., Pala, M., and Bounejmate, M. (2002). Barley based rotations in a typical Mediterranean agroecosystem: Crop production trends and soil quality. Options Mediterraneanes, Series $A$ 50, 287-296.

Ryan, J., Hasbany, R., and Atallah, T. (2003). Factors affecting nitrogen mineralization under laboratory conditions with soils from a wheat-based rotation trial. Lebanese Sci. J. 2, 3-12.

Ryan, J., Masri, S., and Qadir, M. (2006). Nutrient monitoring of sewage wastewater for irrigation: Impacts for soil quality and crop nutrition. Commun. Soil Sci. Plant Anal. 37 (15-20), 2513-2522.

Ryan, J., Pala, M., Singh, M., Makboul, R., Masri, S., and Harris, H. (2008a). Crop sequences nitrogen fertilizer and grazing intensity in relation to wheat yields in rainfed systems. J. Agric. Sci. Camb. (manuscript in preparation).

Ryan, J., Pala, M., Masri, S., Singh, M., and Harris, H. (2008b). Rainfed wheat-based rotations under Mediterranean conditions: Crop sequences, nitrogen fertilization, and stubble grazing in relation to grain and straw quality. Eur. J. Agron. 28, 111-118.

Ryan, J., Pala, M., Masri, S., Singh, M., and Rashid, A. (2008c). Rotation and nitrogen effects on soil nitrogen forms in a multi-year cropping systems trial under rainfed Mediterranean conditions. Iran. J. Sci. Technol. (in review).

Ryan, J., Masri, S., and Singh, M. (2008d). Nutrient dynamics in a long-term cereal-based rotation trial in a Mediterranean environment: Nitrogen forms. Commun. Soil Sci. Plant Anal. (manuscript in preparation).

Ryan, J., Masri, S., and Singh, M. (2008e). Seasonal changes in organic matter and biomass and labile forms of carbon as influenced by Mediterranean crop rotations. Commun. Soil Sci. Plant Anal. (manuscript in preparation).

Ryan, J., Ibrikci, H., Singh, M., Rashid, A., Matar, A., Masri, S., and Pala, M. (2008f). Response to residual and currently applied phosphorus in three Syrian agroecosystem. Eur. J. Agron. 28, 126-137.

Sander, J. A., and Eash, N. S. (1991). Significance of ancient agricultural soil for long-term agronomic studies and sustainable agriculture research. Agron. J. 83, 29-37.

Singh, M., and Jones, M. (1997). Estimating time to detect time-trends in continuous cropping. J. Appl. Stat. 24, 651-661.

Singh, M., and Jones, M. (2002). Modeling yield sustainability for different rotations in longterm barley trials. J. Agric. Biol. Environ. Stat. 7, 525-535.

Singh, M., Yau, S. K., Hamblin, J., and Porceddu, E. (1996). Inter-site transferability of crop varieties: Another approach for analyzing multi-location varietal trials. Euphytica 89(3), 305-311.

Smith, R. G., and Harris, H. C. (1981). Environmental resources and constraints to agricultural production in a Mediterranean-type environment. Plant Soil 58, 31-57.

Steiner, R. A. (1995). Long-term research and their choice for the research study. In "Agriculture Sustainability: Economic, Environmental and Statistical Considerations" (V. Barnett, R. Payne, and R. Steiner, Ed.), pp. 15-21. John Wiley \& Sons, Chichester, UK.

Steiner, R. A., and Herdt, R. W. (1993). "A Global Directory of Long-Term Agronomic Experiment.”. The Rockefeller Foundation, New York, NY, USA. 
Steiner, J. L., Day, J. C., Papendick, R. I., Mayer, R. E., and Bertrand, A. R. (1988). Improving and sustaining productivity in dryland regions of developing countries. $A d v$. Soil Sci. 8, 79-122.

Stewart, B. A., and Robinson, C. A. (1997). Are ecosystems sustainable in semiarid regions. Adv. Agron. 60, 191-228.

Stewart, B. A., Koohafkan, P., and Ramamoorthy, K. (2006). Dryland agriculture defined and its importance in the world. In "Dryland Agriculture" (G. A. Peterson, P. W. Unger, and W. A. Payne, Eds.), pp. 1-26. Agronomy Monograph No. 23, American Society of Agronomy, Crop Science Society America, Madison, WI, USA.

Suleimenov, M. K., Okhmetov, K. A., Kaskarbayev, J. A., Khasanova, F., Kireyev, A., Kyrgyz, L. I., and Pala, M. (2004). Developments in tillage and cropping systems in Central Asia. In "Agriculture in Central Asia: Research for Development" ( J. Ryan, P. Vlek, and R. Paroda, Eds.), pp. 188-211. ICARDA, Aleppo, Syria, and ZEF, Bonn, Germany.

Taimeh, A., Al-Nabi Ferdous, A., and Al-Shrouf, A. (1999). Review of optimizing soil water-use research in Jordan. In "Efficient Soil Water Use: The Key to Sustainable Crop Production in Dry Areas" (N Duivenbooden, M. Pala, C. Studer, and C. L Bilders, Eds.), ICARDA, Aleppo, Syria, and ICRISAT, Patancheru, Andhra Pradesh, India.

Van Duivenbooden, N., Pala, M., Studer, C., and Bilders, C. (1999). Efficient soil water use: The key to sustainable crop production in the dry areas of West Asia, and North and SubSaharan Africa. ICARDA, Aleppo, Syria, and ICRISAT, Andhra Pradesh, India.

White, P. F., Nersoyan, N. K., and Christensen, S. (1994). Nitrogen cycling in a semi-arid Mediterranean region: Changes in soil $\mathrm{N}$ and organic matter under several crop livestock production systems. Aust.J.Agric.Res. 45, 1293-1307.

Yau, S. K., Nachit, M., Ryan, J., and Hamblin, J. (1995). Phenotypic variation of boron tolerance toxicity in durum wheat at seedling stage. Euphytica 83, 185-191.

Yau, S. K., Bounejmate, M., Ryan, J., Baalbaki, R., Nassar, A., and Maacoroum, R. (2003). Barley-legumes rotations for semi-arid areas of Lebanon. Eur. J. Agron. 19, 599-610.

Zhang, H., Oweis, T. Y., Garabet, S., and Pala, M. (1998). Water-use efficiency and transpiration efficiency of wheat under rainfed conditions and supplemental irrigation in a Mediterranean type environment. Plant Soil 201, 295-305.

Zhang, H., Pala, M., Oweis, T., and Harris, H. (2000). Water use efficiency of chickpea and lentil in a Mediterranean environment. Aust. J. Agric. Res. 51, 295-304. 